\title{
In Vitro Analysis of Antioxidant, Anticancer, and Bioactive Components of Apocynum venetum Tea Extracts
}

\author{
Chong Li, ${ }^{1,2,3}$ Guangbin Huang, ${ }^{4}$ Fang Tan, ${ }^{5}$ Xianrong Zhou, ${ }^{1,2,3}$ Jianfei Mu, ${ }^{1,2,3}$ \\ and Xin Zhao ${ }^{1,2,3}$ \\ ${ }^{1}$ Chongqing Collaborative Innovation Center for Functional Food, Chongqing University of Education, Chongqing 400067, China \\ ${ }^{2}$ Chongqing Engineering Research Center of Functional Food, Chongqing University of Education, Chongqing 400067, China \\ ${ }^{3}$ Chongqing Engineering Laboratory for Research and Development of Functional Food, Chongqing University of Education, \\ Chongqing 400067, China \\ ${ }^{4}$ Department of Trauma Surgery, Emergency Medical Center of Chongqing, \\ The Affiliated Central Hospital of Chongqing University, Chongqing 400030, China \\ ${ }^{5}$ Department of Public Health, Our Lady of Fatima University, Valenzuela 838, Philippines
}

Correspondence should be addressed to Xin Zhao; zhaoxin@cque.edu.cn

Received 18 August 2019; Revised 14 October 2019; Accepted 22 October 2019; Published 16 November 2019

Academic Editor: Efstathios Giaouris

Copyright (c) 2019 Chong Li et al. This is an open access article distributed under the Creative Commons Attribution License, which permits unrestricted use, distribution, and reproduction in any medium, provided the original work is properly cited.

The dry leaf of Apocynum venetum tea extracts (AVTEs) belonging to the Apocynaceae family is a traditional Chinese medicine. The aim of this study is to identify the bioactive components of AVTE and analyse its antioxidant and anticancer activity in vitro. Method. Flavones and polyphenols in AVTE were determined by high-performance liquid chromatography (HPLC) assay. The scavenging capacity of tea extracts to 1,1-diphenyl-2-picrylhydrazyl (DPPH); 2,2'-azino-bis-(3-ethylbenzthiazoline-6-sulfonic acid) diammonium salt (ABTS); hydroxyl $(\mathrm{OH})$; and superoxide anion-free radicals were investigated by spectrophotometry. We also detailed the cytotoxicity assay of AVTE $(50,100$, and $200 \mu \mathrm{g} / \mathrm{mL})$ to human embryonic kidney $293 \mathrm{~T}$ cells, the protective effect of AVTE on 293T cells induced by hydrogen peroxide $(0.3 \mathrm{mmol} / \mathrm{L})$, and the anticancer effect against the human hepatoma HepG2 cells via 3-(4,5-dimethyl-2-thiazolyl)-2,5-diphenyl-2-H-tetrazolium bromide (MTT) assay. We investigated the antioxidative effects of AVTE in human embryonic kidney 293T cells and the anticancer mechanism in HepG2 human hepatoma cells via quantitative real-time reverse transcription-polymerase chain reaction (RT-qPCR) assay. Results. HPLC analysis showed that AVTEs contain neochlorogenic acid, chlorogenic acid, rutin, isoquercetin, isochlorogenic acid B, astragalin, isochlorogenic acid $\mathrm{C}$, rosmarinic acid, quercetin, and trans-cinnamic acid. These extracts have high antioxidant activity and dose-dependent relation through free radical scavenging experiments. The cell viability of $293 \mathrm{~T}$ cells treated with hydrogen peroxide $(0.3 \mathrm{mmol} / \mathrm{L})$ was significantly lower than that of normal cells, and the cell viability of oxidatively stressed 293T cells after AVTE (50, 100, and $200 \mu \mathrm{g} / \mathrm{mL}$ ) treatment was significantly improved $(P<0.05)$. Moreover, cytotoxicity experiments showed that the survival rate of 293 T cells was over 90\%, but the proliferation of HepG2 cells was significantly inhibited in a dose-dependent manner by AVTE. Furthermore, cytoprotective effects in 293T cells were induced via upregulation of glutathione peroxidase (GSH-Px), GSH, superoxide dismutase (SOD), and catalase (CAT) antioxidant-related factors, as well as apoptosis in HepG2 cells was induced via upregulation of caspase-3, caspase-9, p21, and p53 apoptosis-associated factors, as assessed via mRNA expression levels after treatment with AVTE, which were consistent with the results of antioxidant gene detections. As a conclusion, AVTE appears to be an effectively functional drink, due to its rich functional components and antioxidant and anticancer activities.

\section{Introduction}

Apocynum venetum belongs to the Oleander family and has the following three species: Apocynum venetum $\mathrm{L}$, Poacynum hendersonii (Hook.f) Woodson, and Poacynum pictum (Sckrenk) Baill [1]. Apocynum venetum tea (from the Apocynum Plain in Xinjiang, China) was processed from the young leaves of Apocynum venetum L., which were dried at 
appropriate temperature and humidity, and they form a unique flavor and taste due to their own fermentation and a series of complex chemical changes. According to the reports, the raw leaves mainly contain chemical components such as flavonoids, organic acids, tannins, fatty acid alcohol esters, sterols, glycosides, alkanes, amino acids, and mineral elements, and it has shown many health functions such as regulating blood pressure, lowering blood fat and depression, calming the nerves, protecting the liver, protecting the kidney from diuresis, strengthening the heart, delaying aging, inhibiting platelet aggregation, inhibiting bacteria, resisting anxiety, and promoting immunity [2-4].

Aging is an unavoidable, universal, biological law, the causes of which are loss of function, resistance to stress, and adaptability. The current mechanism of aging is still unclear, and the most widely accepted reason is the theory of free radicals, which states that when the body ages, the free radicals in the body are mainly increased in oxygen free radicals, and the free radical-generating system of the body is out of balance with the scavenging system. Excessive free radicals induce lipid peroxidation, causing damage to biological macromolecules, ultimately leading to the aging and dysfunction of the body that trigger inflammation, molecular degradation, and other types of diseases such as cardiovascular diseases, nervous system diseases, and cancer [5]. Studies have shown that aging is closely related to the body's SOD activity and malondialdehyde (MDA) content. MDA is the main product of lipid peroxidation, reflecting the extent of oxidative damage. SOD, present widely in organisms, is a key enzyme in the body's antioxidant system. Its activity is closely related to aging and cancer [6]. In addition to the body's own resistance system (such as antioxidant enzymes and proteins), antioxidants can also capture and stabilize free radicals, such as ascorbic acid, vitamin E, polyphenols, and other exogenous small molecules, to protect cells from free radical damage [7]. As a functional beverage, AVTE is rich in polyphenols, flavonoids, organic acids, and other bioactive substances, which can provide antioxidants and reduce the damage of free radicals [8].

Hepatocellular carcinoma (HCC) is one of the top 10 most common cancers in the world, with the highest mortality rate worldwide. The incidence and mortality of HCC in China account for about half of the world's morbidity and mortality [9]. It has the characteristics of insidious onset, strong metastasis, rapid progress, and easy recurrence. The incidence of liver cancer involves a variety of factors, including environmental stimuli, genetic variation, and multistage accumulation, while the progress is slow with no characteristic signs. The onset is often in the middle and late stages, and the treatment effect is poor. Only by early detection, diagnosis, and treatment should the liver cancer mortality be reduced [10]. At present, the diagnostic methods for liver cancer are performed mainly by imaging examination (B-ultrasound, computed tomography (CT), magnetic resonance imaging (MRI), etc.), serological examination (liver function, hepatitis B virus, alpha-fetoprotein, etc.), and histopathological examination performed through liver biopsy. Treatment methods include surgery, radiation therapy, chemotherapy, and traditional Chinese medicine [11]. The bioactive ingredients in traditional Chinese medicines and some foods can prevent different types of cancer at the early stage by improving human immunity or can be used in surgery, radiotherapy, and chemotherapy to alleviate the symptoms of patients with advanced cancer and improve the quality of life. For example, drinking tea can benefit liver cancer patients in surgery, chemotherapy, and radiation therapy [6].

Hence, AVTE was used as a raw material to investigate its potential bioactive compounds using HPLC, and their protective effect on oxidatively damaged $293 \mathrm{~T}$ cells and anticancer effect on human hepatoma HepG2 cells were explored through in vitro experiments.

\section{Materials and Methods}

2.1. Preparation of AVTE. Apocynum venetum tea (brand: Niamese; specification: $250 \mathrm{~g} / \mathrm{tank}$ ) was purchased from Xinjiang Lvkang Apocynum Co., Ltd., originated in China's Xinjiang Apocynum Plain. The Apocynum venetum tea was crushed, freeze-dried at $-50^{\circ} \mathrm{C}$ and $2.0 \mathrm{~Pa}$ and then subsequently ground into separate fine powders. A twenty-fold volume of $70 \%$ ethanol was added to the powdered samples and extracted at $60^{\circ} \mathrm{C}$ for $3 \mathrm{~h}$. The extract was filtered with FL-3 macroporous resin, eluted with $70 \%$ ethanol until colorless and evaporated using a rotary evaporator (N-1100; Eywla; Tokyo, Japan) to remove water and ethanol to obtain a flavonoid extract and then freeze dried $\left(-50^{\circ} \mathrm{C}, 2.0 \mathrm{~Pa}\right)$ and stored at $4^{\circ} \mathrm{C}$ until needed.

2.2. Chemical Standards. Quercetin, isoquercetin, and astragalin were obtained from Sigma-Aldrich Chemical Co. (St. Louis, MO, USA). Chlorogenic acid, rosmarinic acid, and trans-cinnamic acid were obtained from Fluka Chemical Co. (Buchs, Switzerland). Neochlorogenic acid, isochlorogenic acid $\mathrm{B}$, and isochlorogenic acid $\mathrm{C}$ were purchased from Solarbio Technology Co. (Beijing, China). Rutin was obtained from Keli Technology Development Co. Guangzhou Testing Center (Guangzhou, China).

2.3. HPLC Analysis. The AVTE was dissolved in DMSO to obtain a solution with a concentration of $10 \mathrm{mg} / \mathrm{mL}$ and diluted with $70 \%$ methanol to produce a final concentration of $2.5 \mathrm{mg} / \mathrm{mL}$. The sample was passed through a $0.22 \mu \mathrm{m}$ organic filter before testing. About $10 \mu \mathrm{L}$ of the diluted AVTE sample solution was analyzed using an UltiMate3000 HPLC System (Thermo Fisher Scientific, Inc., Waltham, MA, USA) and separated using an Accucore C18 column $(2.6 \mu \mathrm{m}, 4.6 \times 150 \mathrm{~mm}$; Thermo Fisher Scientific, Inc., USA). Mobile phase A was water containing $0.5 \%$ acetic acid, and mobile phase $B$ was acetonitrile. The flow rate was $0.5 \mathrm{~mL} /$ min with a column temperature of $30^{\circ} \mathrm{C}$, and the detection wavelength was $359 \mathrm{~nm}$. The gradient elution conditions were as follows: equilibrium stage was set for $10 \mathrm{~min}$ with $12 \% \mathrm{~B}$ (isocratic) and 0-30 min with 12\%-45\% B (linear gradient) [12]. 
2.4. DPPH Free Radical Scavenging Activity. A total of $0.3 \mathrm{~mL}$ of different concentrations $(0.2,0.6$, and $1.0 \mathrm{mg} / \mathrm{mL})$ of AVTE was added to $2.0 \mathrm{~mL}$ of DPPH ethanol solution $(0.63 \mathrm{mM})$, mixed, and allowed to stand in the dark for $30 \mathrm{~min}$ at room temperature. The absorbance of the solution was measured at $517 \mathrm{~nm}$ using a UV-visible spectrophotometer (BioMate 3S; Thermo Fisher Scientific, Inc., Waltham, MA, USA). Ascorbic acid $(0.2 \mathrm{mg} / \mathrm{mL})$ was used as a positive control. Each group of data was measured three times in parallel [13].

2.5. OH Free Radical Scavenging Activity. About $2 \mathrm{~mL}$ of PBS solution ( $\mathrm{pH} 7.4,0.01 \mathrm{M}), 1.0 \mathrm{~mL}$ of phenanthroline reagent $(7.50 \mathrm{M}), 1.0 \mathrm{~mL}$ of ferrous sulfate solution $(7.50 \mathrm{M})$, $3.0 \mathrm{~mL}$ of $\operatorname{AVTE}(0.2,0.6,1.0 \mathrm{mg} / \mathrm{mL})$, and $2.0 \mathrm{~mL}$ of hydrogen peroxide solution $(0.06 \%)$ were mixed in the aforementioned order. The reaction system was placed in a water bath at $37^{\circ} \mathrm{C}$ for $60 \mathrm{~min}$, and the absorbance was measured at $536 \mathrm{~nm}$. Ascorbic acid $(0.2 \mathrm{mg} / \mathrm{mL})$ was used as a positive control. Sample absorbance and background absorbance were deducted. These experimental procedures were repeated three times [14].

2.6. ABTS Free Radical Scavenging Activity. The ABTS reagent $(6.83 \mathrm{mM})$ was mixed (volume, $1: 1$ ) with $\mathrm{K}_{2} \mathrm{~S}_{2} \mathrm{O}_{8}$ $(2.47 \mathrm{mM})$ and oxidized in darkness at room temperature for $12 \mathrm{~h}$. The absorbance of ABTS reagent was diluted with absolute ethanol to $0.7 \pm 0.02(734 \mathrm{~nm})$. A total of $1.0 \mathrm{~mL}$ AVTE $(0.2,0.6$, and $1.0 \mathrm{mg} / \mathrm{mL})$ with different concentrations was added to the $2.0 \mathrm{~mL}$ ABTS working solution. The extracts were mixed and placed in a dark environment for $10 \mathrm{~min}$ at room temperature. Absorption was measured at $734 \mathrm{~nm}$. Ascorbic acid $(0.2 \mathrm{mg} / \mathrm{mL})$ was used as a positive control. The sample absorbance and background absorbance were deducted. These experimental procedures were repeated three times [15].

\subsection{Superoxide Anion Free Radical Scavenging Activity.} The pyrogallol autoxidation method was adopted. A total of $0.5 \mathrm{~mL}$ of different concentrations $(0.2,0.6$, and $1.0 \mathrm{mg} / \mathrm{mL})$ of AVTE and $4.5 \mathrm{~mL}$ of $0.1 \mathrm{~mol} / \mathrm{L}$ Tris- $\mathrm{HCl}(\mathrm{pH}=8.2)$ buffer were added to the reaction system, and then the mixed system was reacted in a $37^{\circ} \mathrm{C}$ water bath for $20 \mathrm{~min}$ and cooled to room temperature. Then $0.4 \mathrm{~mL}$ of $50 \mathrm{mmol} / \mathrm{L}$ pyrogallol solution was added to the cooled mixed system and reacted in a $37^{\circ} \mathrm{C}$ water bath for $5 \mathrm{~min}$, and $0.1 \mathrm{~mL}$ of $8.0 \mathrm{~mol} / \mathrm{L}$ concentrated $\mathrm{HCl}$ was immediately added to terminate the reaction, and the absorbance value was measured at $320 \mathrm{~nm}$. Ascorbic acid $(0.2 \mathrm{mg} / \mathrm{mL})$ was used as a positive control. Each group of data were measured three times in parallel. To prepare $0.1 \mathrm{~mol} / \mathrm{L}$ Tris- $\mathrm{HCl}(\mathrm{pH}=8.2)$ buffer, $50 \mathrm{~mL}$ of $0.1 \mathrm{~mol} / \mathrm{L}$ Tris solution was dissolved in $22.9 \mathrm{~mL}$ of $0.1 \mathrm{~mol} / \mathrm{L}$ hydrochloric acid solution and made up to $100 \mathrm{~mL}$ with deionized water [16].

2.8. Cell Culture Preparation. Human embryonic kidney 293T cells and human hepatoma HepG2 cells were obtained from the Shanghai Institute of Biochemistry and Cell Biology (SIBCB, Shanghai, China). 293T cells were used for oxidative damage tests and HepG2 cells for anticancer tests. 293T cells were distributed in Dulbecco's modified eagle medium (DEME) (high glucose, containing 10\% fetal bovine serum and $1 \%$ penicillin-streptomycin bi-antibody solution), and the cancer cells were distributed in Roswell Park Memorial Institute-1640 (RPMI-1640) medium (containing $10 \%$ fetal bovine serum and $1 \%$ penicillin-streptomycin biantibody solution), both of which were cultured in a saturated moist environment of $37^{\circ} \mathrm{C}$ and $5 \%$ carbon dioxide (model 311 S/N29035; Forma, Waltham, MA, USA). The medium was replaced two to three times a week. When the culture reached approximately 90\% confluency, cells were trypsinized with trypsin $(0.25 \%)$.

2.9. MTT Assays. AVTE on $293 \mathrm{~T}$ cytotoxicity assay: the suspension of $293 \mathrm{~T}$ cells $\left(180 \mu \mathrm{L}, 1 \times 10^{4}\right.$ cells $\left./ \mathrm{mL}\right)$ was inoculated into 96 -well cell culture plates and cultured at $37^{\circ} \mathrm{C}$ in $5 \% \mathrm{CO}_{2}$ for $24 \mathrm{~h}$ to allow the cells to adhere. Different concentrations of AVTE $(20 \mu \mathrm{L}, 0,50,100$, and $200 \mu \mathrm{g} / \mathrm{mL})$ were added to the suspension and incubated for another $24 \mathrm{~h}$. After adding $20 \mu \mathrm{L}$ of $5 \mathrm{mg} / \mathrm{mL}$ MTT (Ekear; Shanghai, China) reagent to each well, the suspension was mixed and cultured for $4 \mathrm{~h}$, the upper medium was removed, $150 \mu \mathrm{L}$ of dimethyl sulfoxide (DMSO) was added, and the whole suspension was mixed at $37^{\circ} \mathrm{C}$ for $30 \mathrm{~min}$ in dark conditions at a constant temperature of $40^{\circ} \mathrm{C}$. The absorbance of each well was detected at $490 \mathrm{~nm}$ using an enzyme-linked immunosorbent assay reader (model 680; Bio-Rad, Hercules, CA, USA). Each group of data was measured three times in parallel, and the cell viability was calculated by treatment.

Protective effect of AVTE on $\mathrm{H}_{2} \mathrm{O}_{2}$-induced oxidative damage of 293T cells: the 293T cells after adherence (culture conditions as mentioned above) were added to $20 \mu \mathrm{L}$ of $\mathrm{H}_{2} \mathrm{O}_{2}(0.3 \mathrm{mmol} / \mathrm{L})$ and cultured for $4 \mathrm{~h}$ to prepare an oxidative damage model. About $20 \mu \mathrm{L}$ of different concentrations of $\operatorname{AVTE}(0,50,100$, and $200 \mu \mathrm{g} / \mathrm{mL})$ was added to the injury model and cultured for $24 \mathrm{~h}$. After adding $20 \mu \mathrm{L}$ of MTT $(5 \mathrm{mg} / \mathrm{mL})$, the cells were cultured for $4 \mathrm{~h}$, the upper medium was removed, $150 \mu \mathrm{L}$ of DMSO was added, and the mixture was gently blended for $30 \mathrm{~min}$ at $37^{\circ} \mathrm{C}$ in the dark, and the OD value was measured at $490 \mathrm{~nm}$. Each group of data was measured three times in parallel.

The anticancer effect of AVTE on HepG2 cells: a suspension of human hepatoma HepG2 cells $(180 \mu \mathrm{L}$, $1 \times 10^{4}$ cells $/ \mathrm{mL}$ ) was added to 96 -well cell culture plates to allow the cells to adhere to the wall $(24 \mathrm{~h})$. Different concentrations of AVTE $(20 \mu \mathrm{L}, 0,50,100$, and $200 \mu \mathrm{g} / \mathrm{mL})$ was added to the suspension and incubated for $48 \mathrm{~h}$ at $37^{\circ} \mathrm{C}$ and $5 \% \mathrm{CO}_{2}$. Each well was added to a $20 \mu \mathrm{L}$ MTT (Ekear; Shanghai, China) reagent at a concentration of $5 \mathrm{mg} / \mathrm{mL}$ and cultured under the same conditions for $4 \mathrm{~h}$. The supernatant was discarded, and $150 \mu \mathrm{L}$ of DMSO reagent was added to each well and mixed under dark conditions for $30 \mathrm{~min}$ and placed at a constant temperature of $40^{\circ} \mathrm{C}$. The absorbance of each well was measured at $490 \mathrm{~nm}$ by an enzyme-linked immunosorbent assay reader (Model 680; Bio-Rad, 
Hercules, CA, USA) and processed to calculate the cell viability [17].

2.10. RT-qPCR Assays. Human embryonic kidney 293T cells (oxidative damage induced by $0.3 \mathrm{mmol} / \mathrm{L}_{2} \mathrm{H}_{2}$ ) and human hepatoma HepG2 cells were inoculated into sixwell plates $\left(1 \times 10^{5}\right.$ cells/well), respectively, and treated with different concentrations of AVTE $(0,50,100$, and $200 \mu \mathrm{g} /$ $\mathrm{mL}$ ). Total RNA in $293 \mathrm{~T}$ cells or HepG2 cells was isolated using Trizol reagent (Invitrogen, Carlsbad, CA, USA) according to the manufacturer's recommendations, and the concentration and purity of RNA were determined at $260 \mathrm{~nm}$ using a micro-UV-visible spectrophotometer. The total RNA concentration of each group was adjusted to the same level. One microliter of oligo (dt) 18 primer (500 ng) and $1.0 \mu \mathrm{L}$ of total RNA $(1.0 \mu \mathrm{g})$ were added to $10.0 \mu \mathrm{L}$ of nuclease-free water and heated on a gradient PCR instrument for $5 \mathrm{~min}$ at $65^{\circ} \mathrm{C}$ according to the manufacturer's recommendations (RevertAid First-Strand cDNA Synthesis Kit; Thermo Fisher Scientific, Inc., Waltham, MA, USA). Also, a mixed reagent containing $4.0 \mu \mathrm{L}$ of $5 \times$ Reaction Buffer, $1.0 \mu \mathrm{L}$ of Ribolock RNase Inhibitor (20 $\mathrm{U}), 2.0 \mu \mathrm{L}$ of $10 \mathrm{mM}$ dNTP Mix, and $1.0 \mu \mathrm{L}$ of RevertAid Reverse Transcriptase $(200 \mathrm{U} / \mu \mathrm{L})$ was added to the total RNA system; the RNA was reverse transcribed into cDNA under the condition of $60 \mathrm{~min}$ at $42^{\circ} \mathrm{C}$ and $5 \mathrm{~min}$ at $70^{\circ} \mathrm{C}$. The total reaction system $(20 \mu \mathrm{L})$ consists of $1.0 \mu \mathrm{L} c \mathrm{cNA}$, $1 \mu \mathrm{L}$ forward and reverse primers $(10 \mu \mathrm{M})$, respectively, $10.0 \mu \mathrm{L}$ premix (SYBR ${ }^{\circledR}$ Select Master Mix; Thermo Fisher Scientific, Inc., Waltham, MA, USA), and 7.0 $\mu$ L sterilized double-steamed water. They were mixed and reacted on an automatic thermal cycler (SteponePlus, Thermo Fisher Scientific, Inc., Waltham, MA, USA). The amplification conditions were as follows: denatured at $95^{\circ} \mathrm{C}$ for $3 \mathrm{~min}$, annealed at $60^{\circ} \mathrm{C}$ for $30 \mathrm{~s}$, and extended at $95^{\circ} \mathrm{C}$ for $1 \mathrm{~min}$ and cycled 40 times. The expression levels of antioxidant genes GSH-Px, GSH, SOD, and CAT, apoptotic genes caspase- 3 and -9, and growth-inhibiting genes p21 and p53 were determined by RT-qPCR. The sequences of the related primers are shown in Table 1. The cDNA samples of each gene were amplified three times in parallel, and the mean value of $\mathrm{Ct}$ was used for analysis. The internal reference gene is GAPDH, and the levels of the relevant genes were calculated according to $2^{-\Delta \Delta \mathrm{CT}}$ [18].

2.11. Statistical Analysis. The SPSS version 20.0 statistical software (SPSS Inc, Chicago, Illinois, USA) was used to analyze the experimental data. The results were analyzed using one-way analysis of variance (ANOVA) with Duncan's multiple range test, and $P<0.05$ was considered statistically significant. All experiments were repeated three times, and the data were presented as mean \pm standard deviation (SD).

\section{Results and Discussion}

The active components of AVTE are complex and have various physiological functions. Flavonoids and polyphenol active components identified by HPLC have antioxidant, anti-inflammatory, anticancer, and other effects. We found that AVTE has antioxidant and anticancer activity in hepatoma cancer cells in vitro. The specific experimental results are as follows.

3.1. Analysis of the Chemical Composition of AVTE. HPLC analysis of the AVTE is shown in Figure 1(a). Compared with the retention time of the chemical standards (Figure 1(b)), 10 peaks were identified from the AVTE, including neochlorogenic acid (peak 1, $3.87 \mathrm{~min}$ ), chlorogenic acid (peak 2, $5.04 \mathrm{~min}$ ), rutin (peak 3, $10.42 \mathrm{~min}$ ), isoquercetin (peak $4,11.27 \mathrm{~min}$ ), isochlorogenic acid B (peak $5,12.39 \mathrm{~min}$ ), astragalin (peak 6, $13.22 \mathrm{~min}$ ), isochlorogenic acid C (peak 7, $14.19 \mathrm{~min}$ ), rosmarinic acid (peak 8, $14.63 \mathrm{~min}$ ), quercetin (peak 9, $19.81 \mathrm{~min}$ ), and trans-cinnamic acid (peak 10, $21.65 \mathrm{~min}$ ).

The tea trees native to the Bayu region of southern China were first used as a medicinal beverage in China. So far, China's tea production ranks first in the world, which has become one of the most popular traditional beverages in the world. About two-thirds of the population consumes tea [19]. According to the different processing methods and degree of fermentations, tea can be divided into the following categories: green tea (not fermented), white tea (slightly fermented), yellow tea (light fermented), clear tea (oolong tea, semifermented), dark tea (postfermented), black tea (full fermented), and their bioactive ingredients are quite different [20]. Studies have shown that Apocynum venetum tea contains flavonoids, phenolic acids, glycosides, amino acids, and other chemical components, which have the effects of lowering blood pressure, strengthening heart, lowering blood fat and blood sugar, antidepressant, antioxidant, immune promotion, liver protection, and sedation [3]. Tea polyphenols have strong free radical scavenging ability and can also prevent malignant tumors, capture and detoxify various carcinogenic factors, and expose free radicals. These compounds also inhibit the production of nitroso compounds, which possess potent carcinogenic activities, by reducing bisulfite in the digestive organs. As tea polyphenols inactivate enzymes and inhibit viral activity, they are effective against the carcinogenic effects of certain viruses [21]. Isoquercetin is a flavonol glycoside compound, which is easily soluble in organic solvents and has antiinflammatory, antioxidant, antiviral, antitumor, antiatherosclerotic, neuroprotective, blood pressure lowering, and other biological activities [22]. Studies have shown that quercetin can lower blood fat and blood sugar and has antioxidant and antiviral effects. Quercetin has been shown to be a cancer suppressor in many tissues, including the colon, lungs, and intestines [23]. Rutin is a kind of vitamin P genus. It is a hydrogen transporter that may be involved in the action of oxidoreductases in the body, affecting thyroid activity and protecting adrenaline from oxidation. It enhances the action of vitamin $\mathrm{C}$ in the body and promotes its accumulation in the body, maintaining blood vessel elasticity and reducing its permeability and brittleness. Rutin also promotes cell proliferation and prevents blood cell 
TABLE 1: The sequences of reverse transcription-polymerase chain reaction primers.

\begin{tabular}{|c|c|c|}
\hline Accession number & Gene name & Sequence \\
\hline NM_000178.4 & GSH & $\begin{array}{l}\text { Forward: } 5^{\prime} \text { - TAC GGC TCA CCC AAT GCT C- } 3^{\prime} \\
\text { Reverse: } 5^{\prime} \text { - CTA TGG CAC GCT GGT CAA ATA-3 }{ }^{\prime}\end{array}$ \\
\hline NM_201397.2 & GSH-Px & 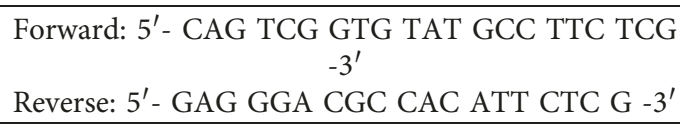 \\
\hline NM_000454.4 & SOD & $\begin{array}{l}\text { Forward: } 5^{\prime} \text { - AGA TGG TGT GGC CGA TGT GT-3' } \\
\text { Reverse: } 5^{\prime} \text { - TCC AGC GTT TCC TGT CTT TGT A- } \\
3^{\prime}\end{array}$ \\
\hline NM_001752.3 & CAT & $\begin{array}{l}\text { Forward: } 5^{\prime} \text {-TGT TGC TGG AGA ATC GGG TTC- } 3^{\prime} \\
\text { Reverse: } 5^{\prime} \text { - TCC CAG TTA CCA TCT TCT GTG } \\
\text { TA-3' }\end{array}$ \\
\hline NM_004346.3 & Caspase-3 & $\begin{array}{l}\text { Forward: 5' - CAT GGA AGC GAA TCA ATG GAC } \\
\text { T-3' } \\
\text { Reverse: } 5^{\prime} \text { - CTG TAC CAG ACC GAG ATG TCA-3' }\end{array}$ \\
\hline NM_032996.3 & Caspase-9 & $\begin{array}{c}\text { Forward: } 5^{\prime} \text { - CTC AGA CCA GAG ATT CGC AAA } \\
\text { C- } 3^{\prime} \\
\text { Reverse: } 5^{\prime} \text { - GCA TTT CCC CTC AAA CTC TCA A- } \\
3^{\prime}\end{array}$ \\
\hline NM_078467.2 & $\mathrm{P} 21$ & $\begin{array}{l}\text { Forward: 5' - TGT CCG TCA GAA CCC ATG C-3' } \\
\text { Reverse: } 5^{\prime} \text { - AAA GTC GAA GTT CCA TCG CTC-3' }\end{array}$ \\
\hline NM_000546.5 & P53 & $\begin{array}{c}\text { Forward: } 5^{\prime} \text { - CTT TGA GGT GCG TGT TTG TGC- } \\
3^{\prime} \\
\text { Reverse: } 5^{\prime} \text { - GGT TTC TTC TTT GGC TGG GGA-3' }\end{array}$ \\
\hline NM_002046.7 & GAPDH & $\begin{array}{c}\text { Forward: } 5^{\prime} \text { - TCA AGA AGG TGG TGA AGC AGG- } \\
\text { 3' } \\
\text { Reverse: } 5^{\prime} \text { - AGC GTC AAA GGT GGA GGA GTG- } \\
3^{\prime}\end{array}$ \\
\hline
\end{tabular}

P21, cyclin-dependent kinase inhibitor 1A; P53, cellular tumor antigen P53.

agglutination and diuretic, antitussive, hypolipidemic, antihypertensive, anticancer, anti-inflammatory, and neuroprotective effects [24]. Astragalin is a natural flavonoid widely existing in medicinal plants. It has anti-inflammatory, antioxidant, cardiotonic, analgesic, antibacterial, antiallergic, antiarrhythmic, and antihepatotoxic effects and can enhance the body's resistance, stimulate the production of interferon, dilate blood vessels, and protect myocardium [25]. Rosmarinic acid, in addition to its antioxidant activity in vitro, also exhibits a wide range of biological activities, including anti-inflammatory, antimutagenic, anticytotoxic, antimetastasis, antiangiogenesis, neuroprotection, antimicrobial, immune regulation, antimelanogenesis, and anti-snake venom [26]. Trans-cinnamic acid is mainly used for cerebral thrombosis, cerebral arteriosclerosis, coronary atherosclerosis, and other diseases, has a significant inhibitory effect on the proliferation of lung adenocarcinoma cells, and has an important application in anticancer activity [27]. Chlorogenic acid is a plant polyphenol that is abundant in human diet and is an ester formed between caffeic acid and quinic acid. It has a different subgroup, including caffeoyl quinic acid, $p$-caffeoyl quinic acid, and ferulic acid, which have antioxidative stress, antiinflammatory, and other activities [28]. Others, such as its isoforms, neochlorogenic acid, isochlorogenic acid $\mathrm{B}$, and isochlorogenic acid $\mathrm{C}$, also have significant pharmacological effects in immunomodulation, tumor suppression, and prevention of cardiovascular diseases [29-31]. Similar to many other studies on tea, the presence of these bioactive chemicals in AVTE may be the main reason for their various pharmacological effects.

3.2. Antioxidant Activities of AVTE. The scavenging ability of the AVTE on DPPH radicals (Figure 2(a)) was assessed at concentrations of $0.2,0.6$, and $1.0 \mathrm{mg} / \mathrm{mL}$, demonstrating radical scavenging activity values of $20.1 \%, 38.7 \%$, and $57.4 \%$, respectively. The scavenging ability of the AVTE to $\mathrm{OH}$ free radical was determined using the phenanthroline- $\mathrm{Fe}^{2+}$ method (Figure 2(b)). The scavenging rate of $1.0 \mathrm{mg} / \mathrm{mL}$ extracts toward hydroxyl radicals was $83.1 \%$, higher than that of $0.2 \mathrm{mg} / \mathrm{mL}$ (33.5\%) or $0.6 \mathrm{mg} / \mathrm{mL}(62.7 \%)$. This indicated that the extracts had a dose-dependent relation with the scavenging capacity toward $\mathrm{OH}$ free radicals. The ABTS radical scavenging ability (Figure 2(c)) of the AVTE in the concentration range of $0.2-1.0 \mathrm{mg} / \mathrm{mL}$ ranged from $22.4 \%$ to $55.9 \%$. The scavenging ability of different concentrations $(0.2,0.6$, and $1.0 \mathrm{mg} / \mathrm{mL})$ of AVTE to superoxide anion radicals (Figure 2(d)) was 25.5\%, $50.0 \%$, and $67.9 \%$, respectively, which was significantly different from controls $(P<0.05)$.

Free radicals are independent chemical substances with unpaired electrons, and when the amount of free radicals exceeds the range of the antioxidant protection system, excessive oxidation occurs, promoting free radicals to attack 


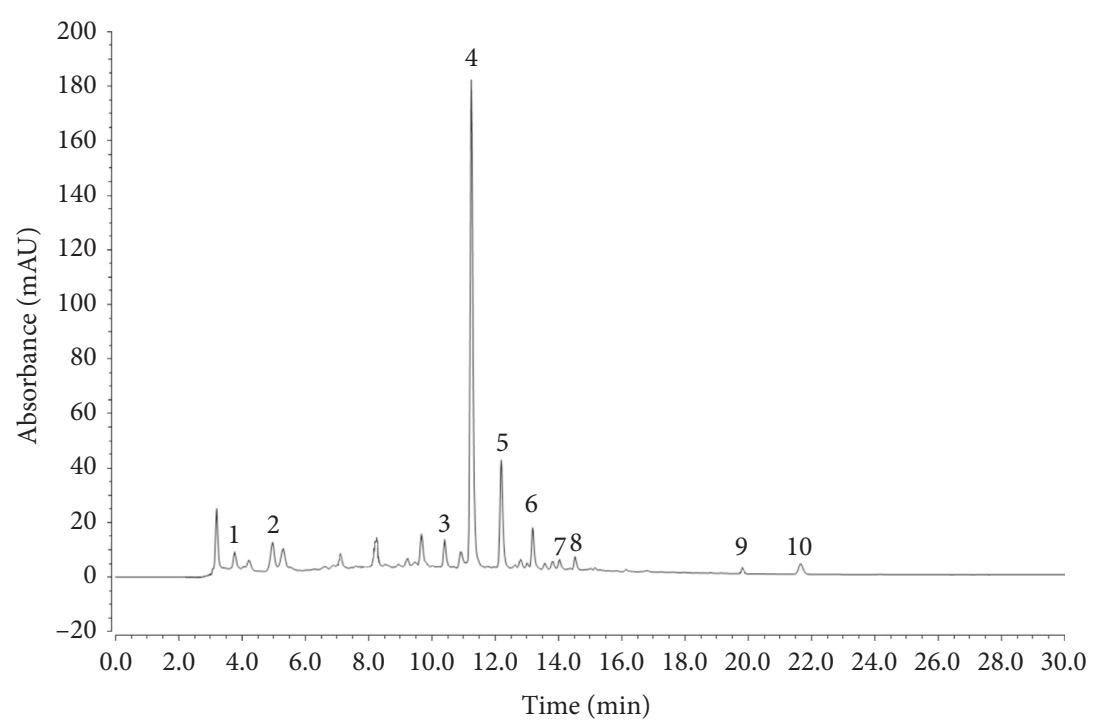

(a)

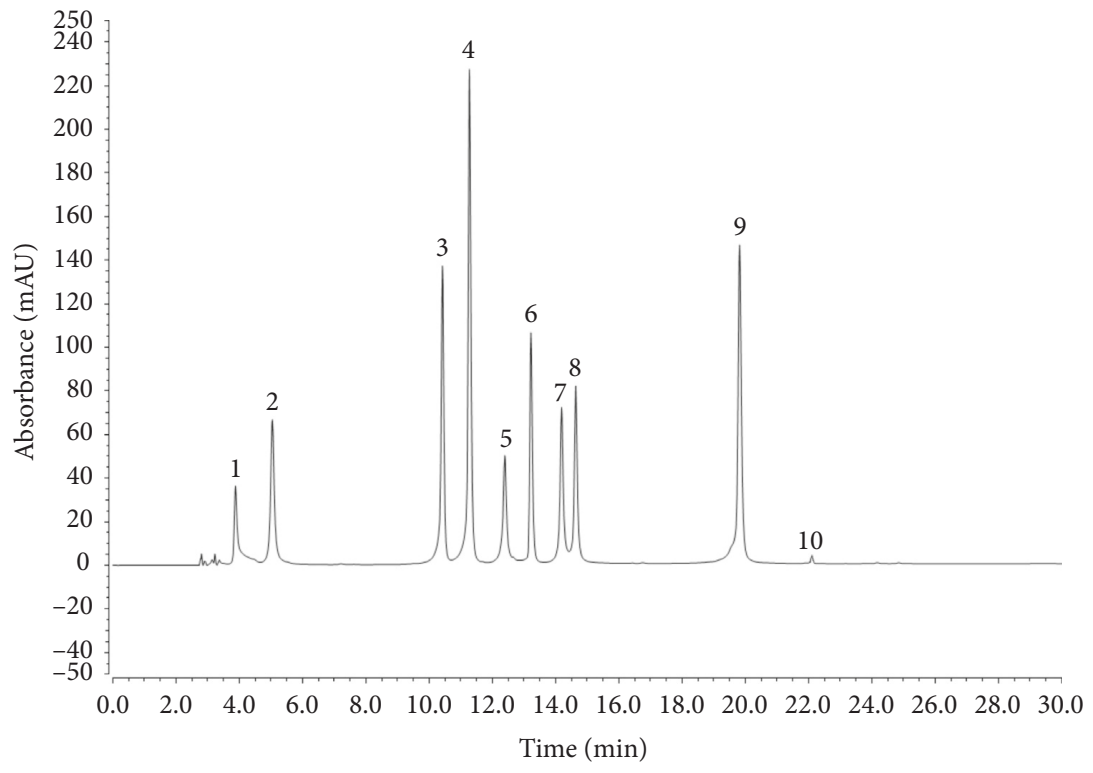

(b)

FIgURE 1: Analysis of the constituents of AVTE via HPLC assay. (a) AVTE chromatogram and (b) standard chromatograms.

the cells of the body to acquire electrons in order to maintain their own stability, causing damage to the conformation and function of cells. To protect the body from free radical damage, humans can resist their own oxidative stress through their own antioxidant system and the ingestion of exogenous antioxidants [32]. The enzyme system includes SOD, CAT, and GSH-Px system, and nonenzymatic antioxidants include gluten, melanin, tocopherol, uric acid, and fatty acids. Compared with the in vivo antioxidant evaluation methods, the in vitro antioxidant evaluation methods are widely used due to their rapidity and convenience, and the exogenous antioxidant provided by the food is essential for the body to resist oxidative stress [33]. Studies have confirmed that polyphenols, ascorbic acid, and carotenoids in plants can improve oxidative stress. Natural antioxidants are excavated from plants, but their efficacy has not been widely recognized, and an accurate and scientific method is needed to evaluate their antioxidant activity [34]. DPPH free radical scavenging assay is one of the most commonly used in vitro antioxidant assays, which has an unpaired valence electron at one atom of the nitrogen bridge. It is a stable free radical with single electron accepting electrons or hydrogen radicals and becomes a stable yellow diamagnetic molecule. The reaction mechanism of the antioxidant with DPPH depends on the structural conformation of the antioxidant [12]. Hydroxyl radicals can induce oxidative damage to DNA, proteins, and lipids, and thus, potential oxidative damage to DNA can be prevented by capturing $\mathrm{OH}$ radicals [13]. Active oxygen can oxidize ABTS to the blue-green cation $\mathrm{ABTS}^{+}$. The addition of an antioxidant active 


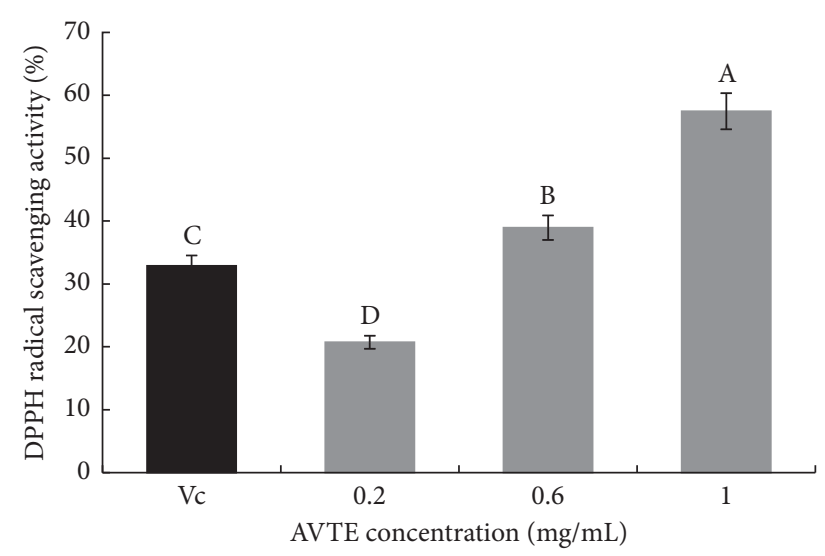

(a)

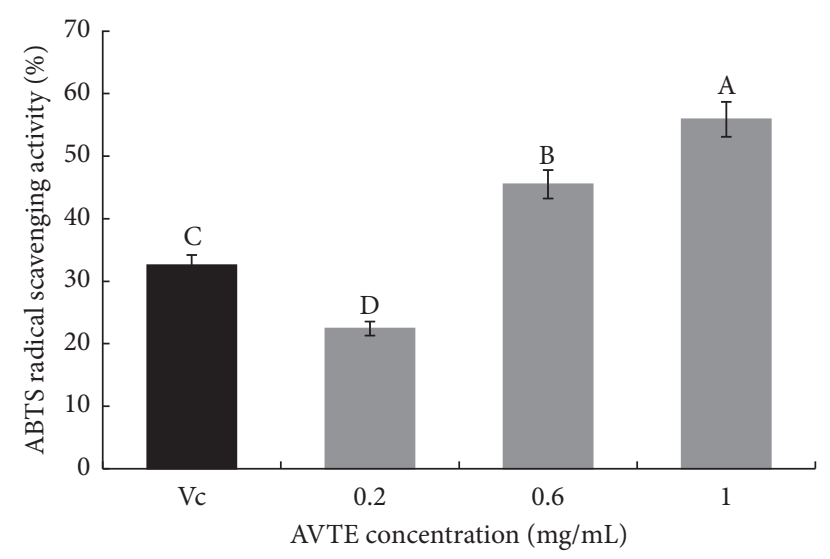

(c)

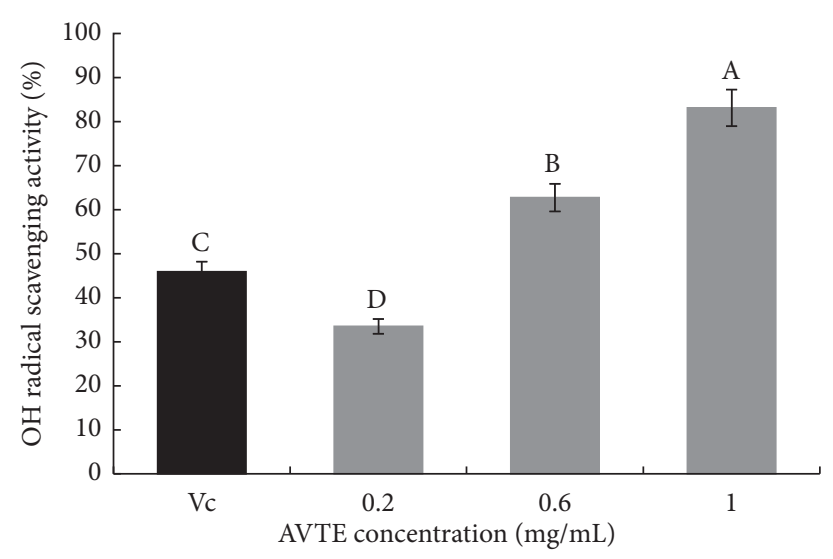

(b)

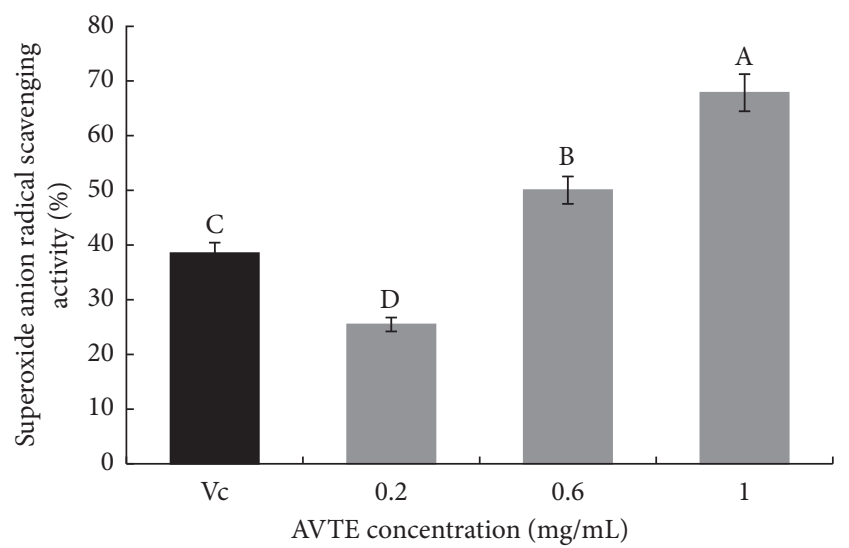

(d)

FIGURE 2: Scavenging activity of AVTE toward 1,1-diphenyl-2-picrylhydrazyl radical (DPPH), hydroxyl radicals (OH), 2,2'-azino-bis (3ethylbenzthiazoline-6-sulphonic acid) diammonium salt radicals (ABTS), and superoxide anion. (a) DPPH radical; (b) OH radical; (c) ABTS radical; and (d) superoxide anion radical. Ascorbic acid was used as positive control in antioxidant experiments. ${ }^{\text {a-d }}$ Mean values with different letters in the same bar graph are significantly different $(P<0.05)$ according to Duncan's multiple range test.

substance can react with $\mathrm{ABTS}^{+}$to discolor the system [14]. The superoxide anion radical is an oxygen radical formed by the ground state oxygen receiving an electron. It can accept an $\mathrm{H}^{+}$to form a conjugate acid, or it can be decomposed into a superoxide anion and an $\mathrm{H}^{+}$, which can cause lipid peroxidation of the cell membrane. The chain reaction of the pyrogallol auto-oxidation system can produce $\mathrm{O}_{2}{ }^{-}$and colored products, and the antioxidant can react with $\mathrm{O}_{2}{ }^{-}$to weaken its luminescence signal [15]. In summary, antioxidants, antioxidant activities, and antioxidant capacity evaluation methods are interrelated, and the determination of antioxidant activity requires a systematic evaluation system. There are many shortcomings in the single in vitro antioxidant evaluation method, and the organic combination of multiple methods is more objective. In this study, $\mathrm{DPPH}, \mathrm{ABTS}, \mathrm{OH}$, and superoxide anion radical scavenging methods were combined to evaluate the in vitro antioxidant effects of AVTE, and the scavenging effect was significantly increased with concentration $(P<0.05)$.

3.3. Assessment of Cell Viability of Damaged 293T Cells and HepG2 Cells (MTT Assay). As shown in Figure 3(a), at different AVTE dosages $(50,100$, and $200 \mu \mathrm{g} / \mathrm{mL}$ ), the cell survival rate toward $293 \mathrm{~T}$ cells exceeded $90 \%$, indicating AVTE in this concentration range $(50-200 \mu \mathrm{g} / \mathrm{mL})$ has no obvious lethal effect on 293T cells. Compared with normal cells, the survival rate of $293 \mathrm{~T}$ cells treated with $\mathrm{H}_{2} \mathrm{O}_{2}$ $(0.3 \mathrm{mmol} / \mathrm{L})$ was significantly decreased (Figure $3(\mathrm{~b}))$, and the cell viability was significantly improved after treatment with 50,100 , and $200 \mu \mathrm{g} / \mathrm{mL}$ of AVTE, and protective effect of high concentration $(200 \mu \mathrm{g} / \mathrm{mL})$ was more significant $(P<0.05)$.

Unlike cell necrosis, cell apoptosis is a spontaneous process, manifested by the autonomous and orderly death of cells controlled by specific genes. It is not a phenomenon of autologous damage under pathological conditions, but a death process that is actively induced to adapt to the living environment and maintain the stability of the internal environment. The system is capable of clearing defective or damaged cells prior to abnormal division and replication in the early stages of cancer cell development. Therefore, it is an effective mechanism for preventing cancer [35]. HCC is one of the most common malignant tumors. Due to the toxic side effects of traditional antitumor therapy, surgery, radiotherapy, and chemotherapy, individual differences also greatly limit the therapeutic effect, resulting in very low 


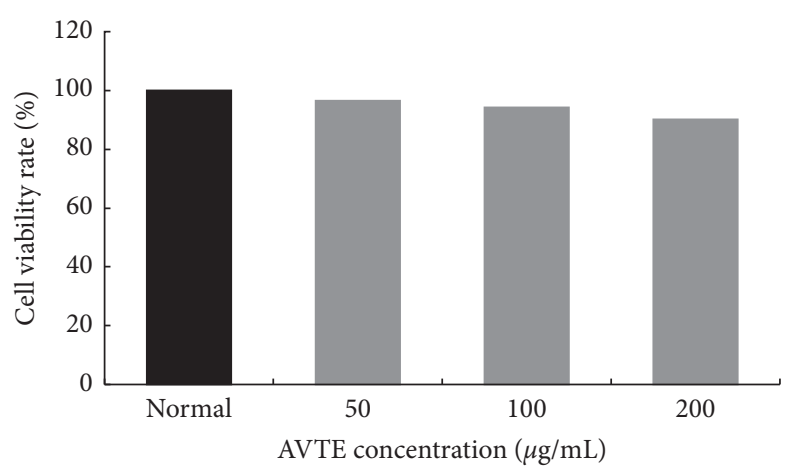

(a)

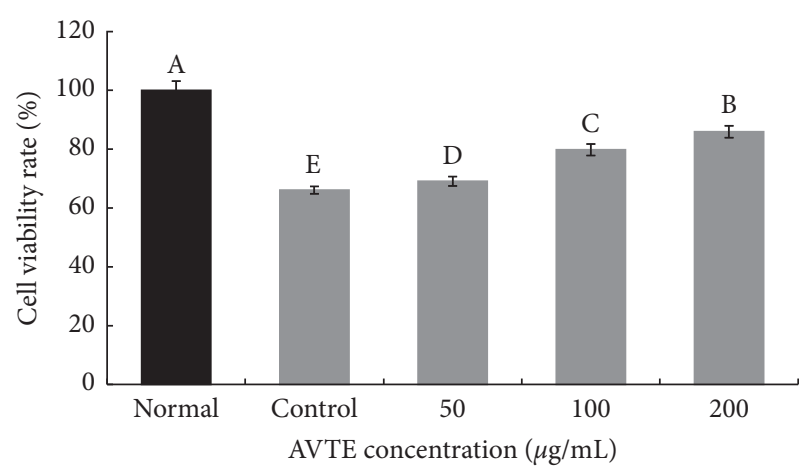

(b)

Figure 3: Cell viability of $293 \mathrm{~T}$ cells was evaluated by using MTT assays. (a) treated with AVTE and (b) treated with AVTE after addition of $\mathrm{H}_{2} \mathrm{O}_{2}(0.3 \mathrm{mmol} / \mathrm{L})$. ${ }^{\mathrm{A}-\mathrm{E}}$ Mean values with different letters in the same bar graph are significantly different $(P<0.05)$ according to Duncan's multiple range test.

survival rate of patients. Precision medicine provides a direction for the prevention and treatment of tumors, but it takes long time and many problems need to be solved, and there is no effective treatment at present [36]. Some ingredients in foods and Chinese herbal medicines have been shown to have selective killing effects on cancer cells, which can prevent liver cancer by means of stimulating apoptosis and inducing apoptosis and death of cancer cells, but have little effect on normal somatic cells [37]. As shown in Figure 4, at different AVTE dosages (50, 100, and $200 \mu \mathrm{g} /$ $\mathrm{mL}$ ), the survival rate toward HepG2 cells was $77.6 \pm 0.6$, $54.4 \pm 0.5$, and $38.9 \pm 0.3$, respectively. The AVTE had a significant and dose-dependent growth inhibitory effect toward HepG2 cells.

\subsection{Effects of AVTE on the MDA Content in Oxidatively} Damaged 293T Cells. As shown in Figure 5, the MDA content of $293 \mathrm{~T}$ cells treated with $\mathrm{H}_{2} \mathrm{O}_{2}(0.3 \mathrm{mmol} / \mathrm{L})$ for $4 \mathrm{~h}$ was significantly higher than normal cells. After treatment with AVTE at different concentrations (50, 100, and $200 \mu \mathrm{g} /$ $\mathrm{mL}$ ), the intracellular MDA content decreased significantly, and the MDA content was the lowest after treatment with $200 \mu \mathrm{g} / \mathrm{mL}$ AVTE.

Studies have shown that the body's aging is closely related to the MDA content and SOD activity in vivo. MDA is the final metabolite of membrane lipid peroxidation in vivo, which can better reflect the extent of tissue peroxidation. MDA released from cell membranes can react with proteins and nucleic acids, cause cross-linking polymerization, and inhibit the synthesis of proteins. It mainly affects the biochemical reactions of normal organisms by damaging the structure and function of the membrane and changing its permeability [38]. As an important form of ROS in vivo, hydrogen peroxide can penetrate cell membranes and react with $\mathrm{Fe}^{2+}$ to produce highly active $\mathrm{OH}$ free radicals, which lead to a series of reactions. It has a wide range of sources and relatively stable properties and can be used as a preferred inducer of oxidative stress [39]. In this study, the MDA content of $293 \mathrm{~T}$ cells was significantly increased after hydrogen peroxide $(0.3 \mathrm{mmol} / \mathrm{L})$

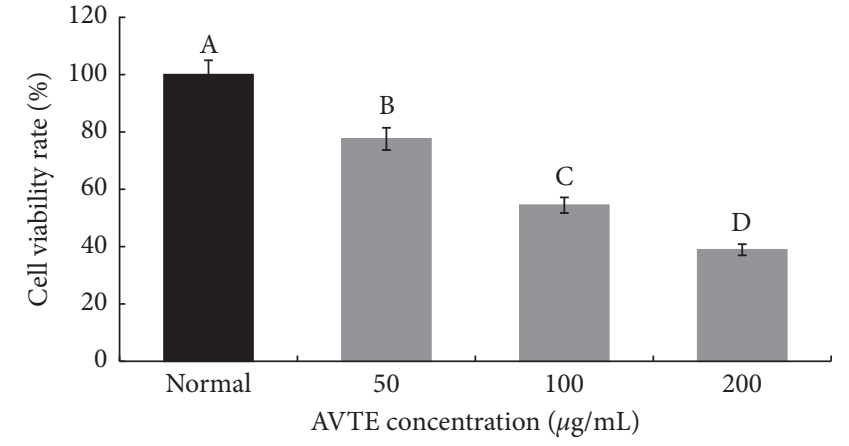

FIgUre 4: Cell viability of HepG2 cells treated with AVTE as evaluated using MTT assays. ${ }^{\text {a-d }}$ Mean values with different letters in the same bar graph are significantly different $(P<0.05)$ according to Duncan's multiple range test.

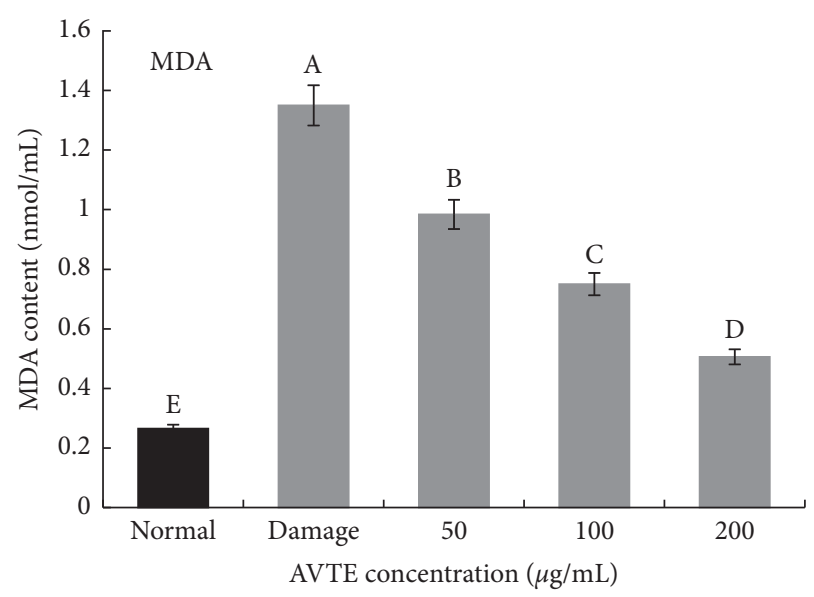

Figure 5: Effect of AVTE on the levels of MDA in 293T cells exposed to $\mathrm{H}_{2} \mathrm{O}_{2} \cdot{ }^{\mathrm{a}-\mathrm{e}}$ Mean values with different letters in the same bar graph are significantly different $(P<0.05)$ according to Duncan's multiple range test.

injury, and the MDA content was significantly decreased after treatment with AVTE at different concentrations (50, 100, and $200 \mu \mathrm{g} / \mathrm{mL} ; P<0.05)$. 


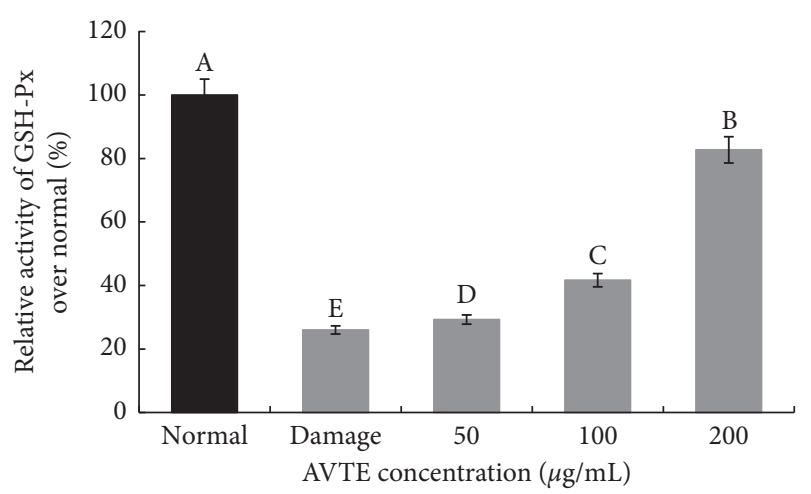

(a)

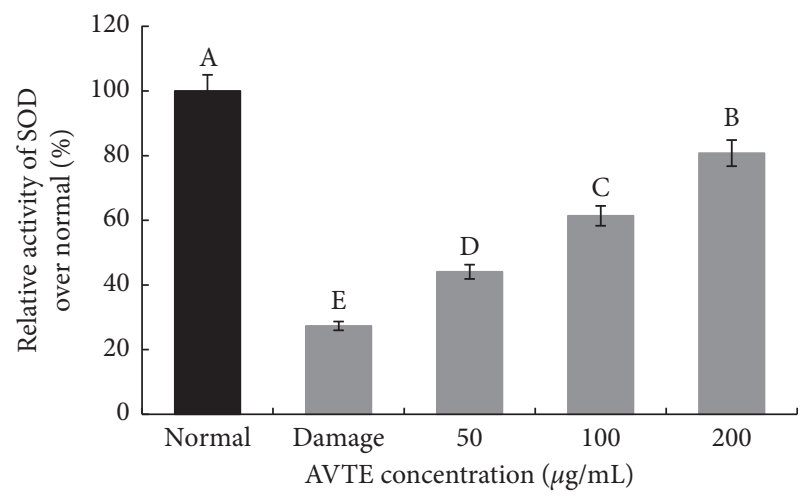

(c)

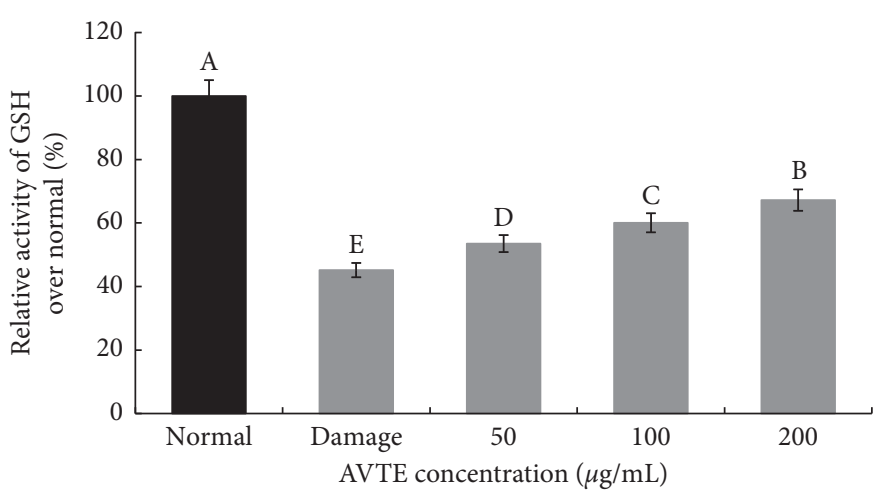

(b)

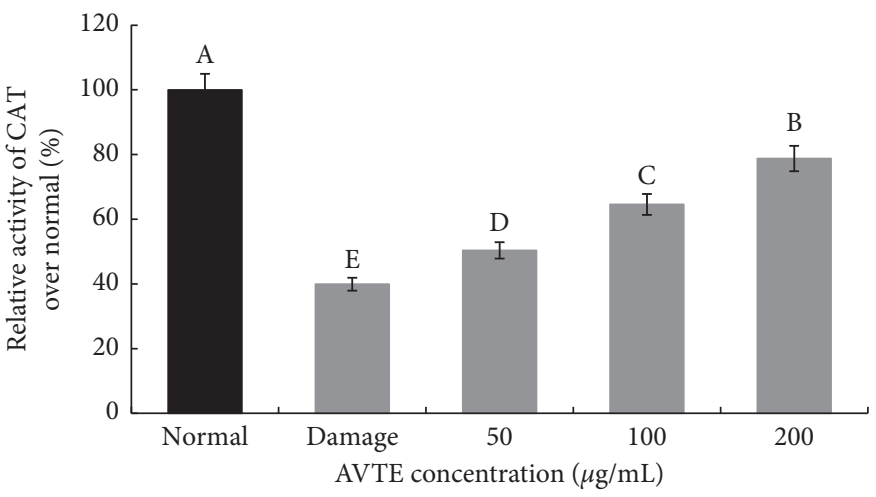

(d)

Figure 6: Effect of AVTE on the levels of SOD, GSH, GSH-Px, and CAT in 293T cells exposed to $\mathrm{H}_{2} \mathrm{O}_{2}$. (a) GSH-Px; (b) GSH; (c) SOD; and (d) CAT. ${ }^{A-E}$ Mean values with different letters in the same bar graph are significantly different $(P<0.05)$ according to Duncan's multiple range test.

3.5. Effects of AVTE on the GSH-Px, GSH, SOD, and CAT Content in Oxidatively Damaged 293T Cells. As shown in Figure 6, the content of GSH-Px, GSH, SOD, and CAT in $293 \mathrm{~T}$ cells treated with $\mathrm{H}_{2} \mathrm{O}_{2}(0.3 \mathrm{mmol} / \mathrm{L})$ for $4 \mathrm{~h}$ was significantly lower than that in normal cells. After treatment with AVTE at different concentrations (50, 100, and $200 \mu \mathrm{g}$ / $\mathrm{mL}$ ), the contents of GSH-Px, GSH, SOD, and CAT in the cells were significantly improved, and the high dose of AVTE had the best effect $(P<0.05)$.

3.6. Effects of AVTE on the Gene Expression of GSH-Px, GSH, SOD, and CAT in Oxidatively Damaged 293T Cells (RT-qPCR Assay). After treatment with $\mathrm{H}_{2} \mathrm{O}_{2}(0.3 \mathrm{mmol} / \mathrm{L})$ for $4 \mathrm{~h}, 293 \mathrm{~T}$ cells were treated with 50,100 , or $200 \mu \mathrm{g} / \mathrm{mL}$ of AVTE for $48 \mathrm{~h}$, and the gene expression of GSH-Px, GSH, SOD, and CAT was evaluated by RT-qPCR analysis. As shown in Figure 7, compared with normal cells, the mRNA expression levels of SOD, CAT, GSH, and GSH-Px in damaged 293T cells were significantly decreased. After the treatment with AVTE, the expression levels of endogenous antioxidant enzymes such as GSH-Px, GSH, SOD, and CAT in the damaged cells were significantly enhanced $(P<0.05)$, which was consistent with the kit test results.

Human endogenous antioxidant enzymes such as CAT, SOD, GSH-Px, and the antioxidant tripeptide GSH can effectively improve oxidative stress damage. According to the auxiliary group combined with different metal ions, SOD is divided into Mn-SOD, Fe-SOD, and Cu/Zn-SOD [40]. Studies have shown that SOD can convert the excess $\mathrm{O}_{2}{ }^{-}$of the body into hydrogen peroxide, which is then converted into $\mathrm{H}_{2} \mathrm{O}$ by CAT and GSH-Px [41]. CAT has a higher affinity for hydrogen peroxide and can reduce toxic hydrogen peroxide to $\mathrm{H}_{2} \mathrm{O}$ [42]. Moreover, GSH can directly react with ROS, reduce it, and act as a substrate for GSH-Px; catalyze the conversion of GSH to GSSG; reduce the lipid peroxides to hydroxyl compounds; and promote the decomposition of hydrogen peroxide [43]. Moreover, AVTE can also enhance its antioxidant activity by upregulating the transcription levels of mRNAs of antioxidant enzymes (CAT, SOD, and GSH-Px) and nonenzymatic antioxidant GSH in oxidative stress-damaged cells, which helps to enhance their antioxidant activity and alleviate cell damage.

3.7. Effects of AVTE on the Gene Expression of the ApoptosisRelated Caspase-3 and -9 Genes in Human Hepatoma HepG2 Cells. Effects on gene expression of apoptotic genes caspase3 and -9 in human hepatoma HepG2 cells were assessed by RT-qPCR assays after $48 \mathrm{~h}$ of treatment with 50,100, or $200 \mu \mathrm{g} / \mathrm{mL}$ of AVTE. As shown in Figures 8(a) and 8(b), compared with the low expression level of the normal group, the expression of the apoptotic genes such as caspase-3 (1.11-, 1.32-, and 2.11-fold) and -9 (1.15-, 1.30-, and 1.65-fold) was 


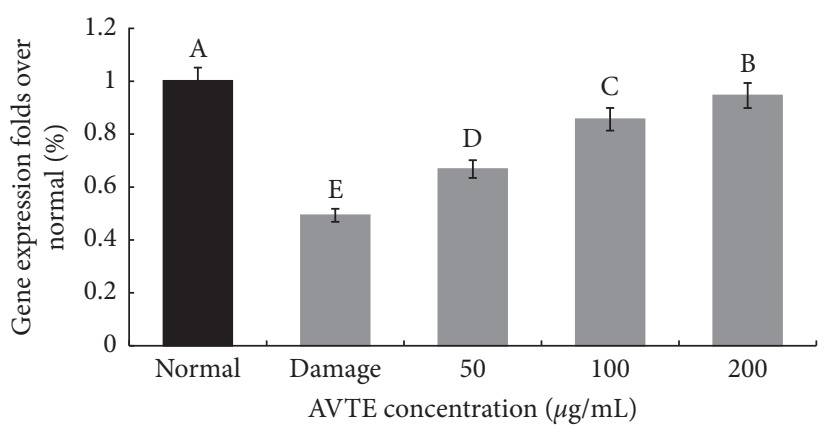

(a)

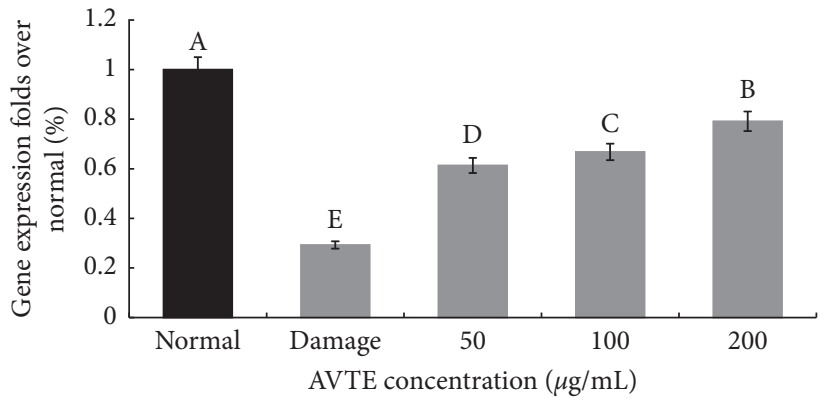

(c)

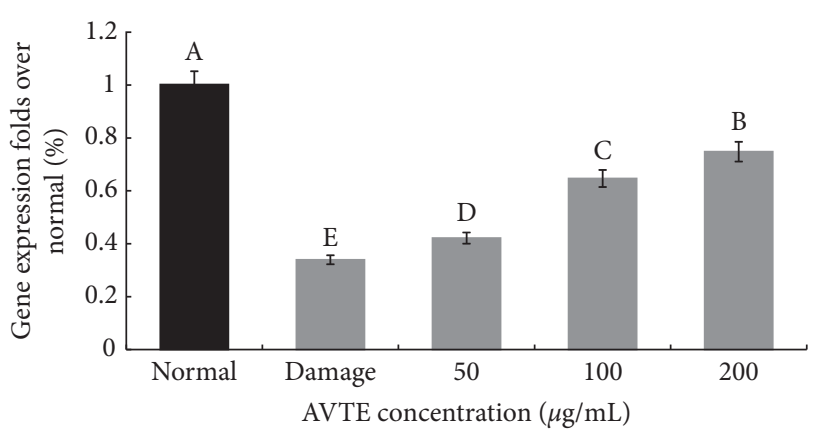

(b)

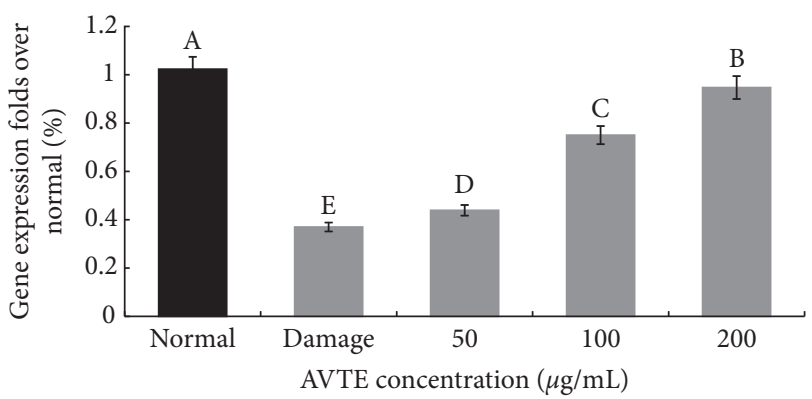

(d)

Figure 7: Effects of AVTE on antioxidant-related GSH-Px, GSH, SOD, and CAT gene expression in 293T cells. (a) GSH-Px; (b) GSH; (c) SOD; and (d) CAT. Fold ratio of GSH-Px, GSH, SOD, and CAT mRNA expression over the normal. The calculation formula is as follows: gene expression/GAPDH $\times$ normal numerical value (normal fold ratio: 1 ). ${ }^{\mathrm{A}-\mathrm{E}}$ Mean values with different letters in the same bar graph are significantly different $(P<0.05)$ according to Duncan's multiple range test.

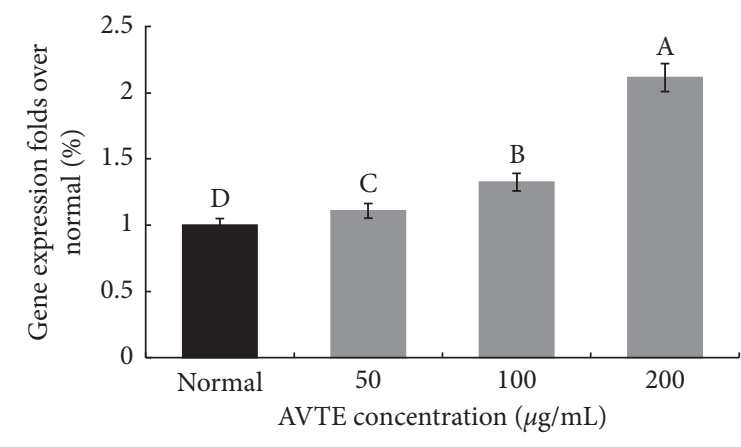

(a)

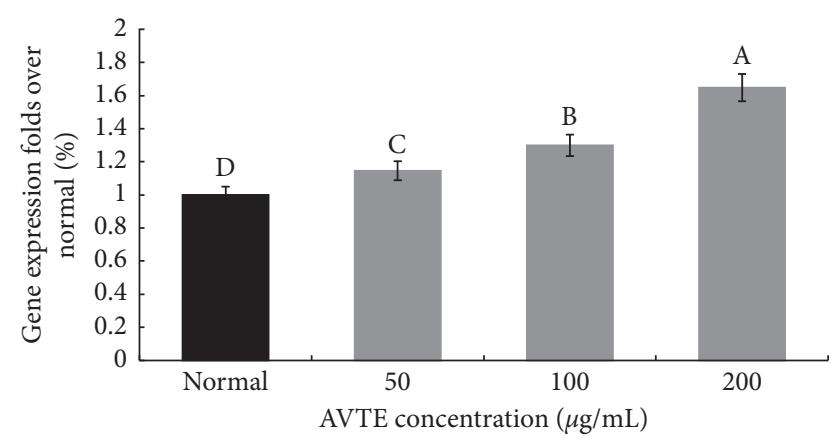

(b)

Figure 8: Effects of AVTE on the apoptotic gene expression of caspase-3 (a) and -9 (b) in human hepatoma HepG2 cells. Fold ratio of caspase-3 (a) and -9 (b) mRNA expression over the normal. The calculation formula is as follows: gene expression/GAPDH $\times$ normal numerical value (normal fold ratio: 1$).{ }^{\mathrm{A}-\mathrm{D}}$ Mean values with different letters in the same bar graph are significantly different $(P<0.05)$ according to Duncan's multiple range test.

significantly increased in the extract-treated cells at concentrations of 50,100 , and $200 \mu \mathrm{g} / \mathrm{mL}$, respectively.

The caspase-signaling cascade is a key event in endogenous and exogenous apoptosis, and caspase- 3 and -9 are the major proteases involved in apoptosis [44]. Caspase- 9 is the initial caspase enzyme located upstream of the apoptotic pathway. Upon activation by different pathways, they are responsible for activating other caspases downstream of the apoptotic pathway, such as caspase-3. As an executor of apoptosis, this cascade induces apoptosis [45]. During this process, proteins such as calpain, cathepsins, and endonucleases perform programmed cell death and enhance cancer cell apoptosis through interaction with caspase [46]. AVTE enhances apoptosis of HepG2 cancer cells by activating endogenous and exogenous apoptotic factors to enhance mRNA expression of caspase-3 and -9 .

3.8. Effects of AVTE on the Gene Expression of the ApoptosisRelated p21 and 553 Genes in Human Hepatoma HepG2 Cells. Treatment with AVTE significantly increased the mRNA expression of p21 (Figure 9(a)) and p53 (Figure 9(b)). The 


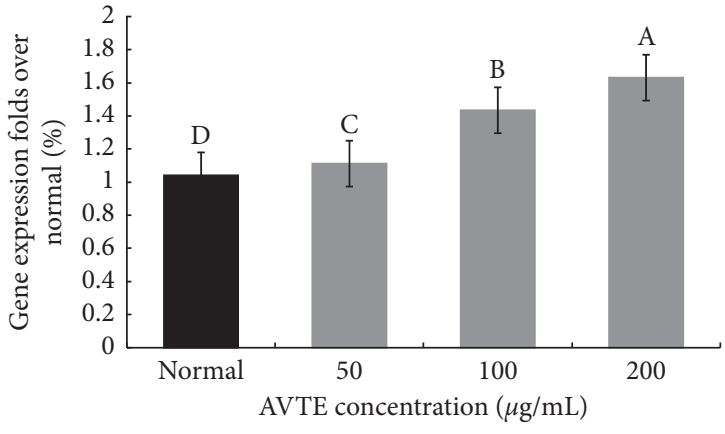

(a)

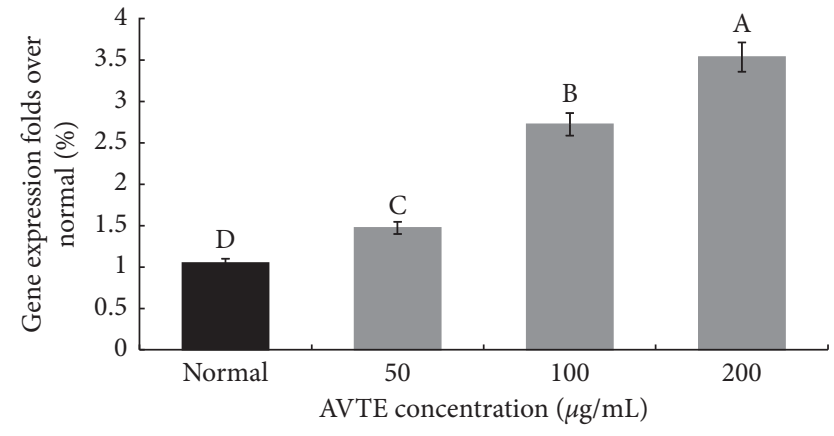

(b)

FIGURE 9: Effects of AVTE on gene expression of the growth-inhibiting gene p21 (a) and the growth-inhibiting and apoptotic gene p53 (b) in human hepatoma HepG2 cells. Fold ratio of p21 (a) and p53 (b) mRNA expression over the normal. The calculation formula is as follows: gene expression/GAPDH $\times$ normal numerical value (normal fold ratio: 1). ${ }^{\mathrm{A}-\mathrm{D}}$ Mean values with different letters in the same bar graph are significantly different $(P<0.05)$ according to Duncan's multiple range test.

highest dose of AVTE $(200 \mu \mathrm{g} / \mathrm{mL})$ significantly increased the mRNA levels of p21 (1.63-fold) and p53 (3.53-fold) compared with the untreated normal group. The 50 and $100 \mu \mathrm{g} / \mathrm{mL}$ concentrations of AVTE also increased the mRNA expression of p21 (1.12- and 1.43-fold, respectively) and p53 (1.47- and 2.72-fold, respectively) in HepG2 cells.

Tumor suppressor p53 monitors and regulates the repair process of DNA damage in G1 phase of cell cycle. If the repair process fails, it can induce apoptosis in many ways [47]. When cells are exposed to hypoxia and DNA damage, p53 can initiate exogenous apoptotic pathways by inducing Fas and FasL expression, interact with members of the Bcl-2 family, promote Bax expression, ultimately change the permeability of mitochondrial membrane and activate caspase in cell membrane, and induce cells to enter the mitochondria-mediated apoptotic pathway (i.e., the endogenous apoptotic pathway) [48]. The relation between $\mathrm{p} 21$ gene and tumor is mainly synergistic with the other related genes. At the expression level, p21 gene has p53-dependent and non-p53-dependent pathways. In the p53dependent pathway, when the organism is damaged, p53 acts as an important activator of p21 and activates the high expression of downstream gene p21, so that cell cycle stagnates in G1, G2, or S phase; DNA replication and mitosis are inhibited; and the cells have time for self-repair. If the repair is unsuccessful, it is mediated into apoptosis [49]. Moreover, high expression of p21 gene was found in transgenic mice, which did not depend on the high expression of p53 gene [50]. In this study, AVTE can induce apoptosis of HepG2 cells by increasing the expression levels of p53 and p21.

\section{Conclusions}

In conclusion, we preliminarily analyzed the potential bioactive substances contained in AVTE and evaluated the antioxidant and anticancer effects of these extracts in vitro. The results showed that ten compounds were detected by HPLC, which have previously been shown to have many biological activities including antioxidation, anticancer, diastolic blood vessels, and others. AVTE had significant scavenging activity against $\mathrm{DPPH}, \mathrm{OH}, \mathrm{ABTS}$, and superoxide anion radicals. AVTE can also reduce 293T cell damage induced by hydrogen peroxide $(0.3 \mathrm{mmol} / \mathrm{L})$ and inhibit the growth of HepG2 cells within a certain concentration range $(50,100$, and $200 \mu \mathrm{g} / \mathrm{mL})$. The RT-qPCR assay also showed that AVTE can prevent aging by regulating the expression of GSH-Px, GSH, SOD, and CAT and stimulate anticancer effects by regulating the expression of caspase-3, -9, p21, and p53. Moreover, these biological activities of AVTE may be conferred by their chemical composition, including flavonoids and phenolic acids. This study, however, was only a preliminary examination of the biological activity and function of AVTE; the specific biological activities, anticancer effects, and mechanisms of various biologically active compounds in the extract will be the topic of future research.

\section{Data Availability}

No data were used to support this study.

\section{Conflicts of Interest}

The authors declare no conflicts of interest.

\section{Authors' Contributions}

Chong Li and Guangbin Huang contributed equally to this work. Chong $\mathrm{Li}$ and Guangbin Huang performed the majority of the experiments and wrote the manuscript; Fang Tan, Xianrong Zhou, and Jianfei Mu contributed to the data analysis; and Xin Zhao designed and supervised the study and read the final manuscript.

\section{Acknowledgments}

This research was funded by the Program for Innovation Team Building at Institutions of Higher Education in Chongqing (CXTDX201601040), the Scientific Research Foundation for Returned Overseas Chinese Scholars, and the State Education Ministry (Jiaowaisiliu (2014)1685) and the Research Project of Chongqing University of Education (KY201921C), China. 


\section{References}

[1] W. Xie, X. Zhang, T. Wang, and J. Hu, "Botany, traditional uses, phytochemistry and pharmacology of Apocynum venetum L. (Luobuma): a review," Journal of Ethnopharmacology, vol. 141, no. 1, pp. 1-8, 2012.

[2] Y. Zhang, C. Liu, Z. Zhang, J. Wang, G. Wu, and S. Li, "Comprehensive separation and identification of chemical constituents from Apocynum venetum leaves by high-performance counter-current chromatography and high performance liquid chromatography coupled with mass spectrometry," Journal of Chromatography B, vol. 878, no. 30, pp. 3149-3155, 2010.

[3] Q. Xiong, W. Fan, Y. Tezuka et al., "Hepatoprotective effect of apocynum venetum and its active constituents," Planta Medica, vol. 66, no. 2, pp. 127-133, 2000.

[4] O. Grundmann, J. Nakajima, S. Seo, and V. Butterweck, "Anti-anxiety effects of Apocynum venetum L. in the elevated plus maze test," Journal of Ethnopharmacology, vol. 110, no. 3, pp. 406-411, 2007.

[5] K. P. Poulianiti, A. Kaltsatou, G. I. Mitrou et al., "Systemic redox imbalance in chronic kidney disease: a systematic review," Oxidative Medicine and Cellular Longevity, vol. 2016, Article ID 8598253, 19 pages, 2016.

[6] C.-X. Ni, H. Gong, Y. Liu, Y. Qi, C.-L. Jiang, and J.-P. Zhang, "Green tea consumption and the risk of liver cancer: a metaanalysis," Nutrition and Cancer, vol. 69, no. 2, pp. 211-220, 2017.

[7] V. Roginsky and E. Lissi, "Review of methods to determine chain-breaking antioxidant activity in food," Food Chemistry, vol. 92, no. 2, pp. 235-254, 2005.

[8] T. Liang, W. Yue, and Q. Li, "Comparison of the phenolic content and antioxidant activities of Apocynum venetum $\mathrm{L}$. (Luo-Bu-Ma) and two of its alternative species," International Journal of Molecular Sciences, vol. 11, no. 11, pp. 4452-4464, 2010.

[9] J. Fu and H. Wang, "Precision diagnosis and treatment of liver cancer in China," Cancer Letters, vol. 412, no. 1, pp. 283-288, 2018.

[10] T. K. Seow, R. C. M. Y. Liang, C. K. Leow, and M. C. M. Chung, "Hepatocellular carcinoma: from bedside to proteomics," Proteomics, vol. 1, no. 10, pp. 1249-1263, 2001.

[11] O. Abdel-Rahman, "Systemic therapy for hepatocellular carcinoma (HCC): from bench to bedside," Journal of the Egyptian National Cancer Institute, vol. 25, no. 4, pp. 165-171, 2013.

[12] H. An, H. Wang, Y. Lan, Y. Hashi, and S. Chen, "Simultaneous qualitative and quantitative analysis of phenolic acids and flavonoids for the quality control of Apocynum venetum L. leaves by HPLC-DAD-ESI-IT-TOF-MS and HPLC-DAD," Journal of Pharmaceutical and Biomedical Analysis, vol. 85, no. 11, pp. 295-304, 2013.

[13] C. Li, C. Liu, J. Zhang et al., "Evaluation of in vitro bio-activities effects of WST (wushanshencha)," Applied Sciences, vol. 9, no. 7, pp. 1325-1342, 2019.

[14] X. Zhao, Q. Wang, G. Li, F. Chen, Y. Qian, and R. Wang, "In vitro antioxidant, anti-mutagenic, anti-cancer and anti-angiogenic effects of Chinese Bowl tea," Journal of Functional Foods, vol. 7, no. 1, pp. 590-598, 2014.

[15] H. Zhang, Y.-F. Yang, Z.-Q. Zhou et al., "Phenolic and flavonoid contents of Mandarin (Citrus reticulata Blanco) fruit tissues and their antioxidant capacity as evaluated by DPPH and ABTS methods," Journal of Integrative Agriculture, vol. 17, no. 1, pp. 256-263, 2018.
[16] S. Marklund and G. Marklund, "Involvement of the superoxide anion radical in the autoxidation of pyrogallol and a convenient assay for superoxide dismutase," European Journal of Biochemistry, vol. 47, no. 3, pp. 469-474, 1974.

[17] X. Zhao, J. Ju, H.-M. Kim, and K.-Y. Park, "Antimutagenic activity and in vitro anticancer effects of bamboo salt on HepG2 human hepatoma cells," Journal of Environmental Pathology, Toxicology and Oncology, vol. 32, no. 1, pp. 9-20, 2013.

[18] H. Suo, P. Sun, C. Wang, D. Peng, and X. Zhao, "Apoptotic effects of insect tea in HepG2 human hepatoma cells," CyTA-Journal of Food, vol. 14, no. 2, pp. 169-175, 2016.

[19] A. Kraszewski and J. Stawinski, "H-phosphonates: versatile synthetic precursors to biologically active phosphorus compounds," Pure and Applied Chemistry, vol. 79, no. 12, pp. 2217-2227, 2007.

[20] V. Danielisova, M. Nemethova, M. Gottlieb, and J. Burda, "The changes in endogenous antioxidant enzyme activity after postconditioning," Cellular and Molecular Neurobiology, vol. 26, no. 7-8, pp. 1181-1191, 2006.

[21] Y. Cai, Q. Luo, M. Sun, and H. Corke, "Antioxidant activity and phenolic compounds of 112 traditional Chinese medicinal plants associated with anticancer," Life Sciences, vol. 74, no. 17 , pp. 2157-2184, 2004.

[22] A. M. Hunter, E. C. LaCasse, and R. G. Korneluk, "The inhibitors of apoptosis (IAPs) as cancer targets," Apoptosis, vol. 12, no. 9, pp. 1543-1568, 2007.

[23] T. K. Seow, R. C. M. Y. Liang, C. K. Leow, and M. C. M. Chung, "Hepatocellular carcinoma: from bedside to proteomics," Proteomics, vol. 1, no. 10, pp. 1249-1263, 2001.

[24] A. Ui, S. Kuriyama, M. Kakizaki et al., "Green tea consumption and the risk of liver cancer in Japan: the Ohsaki Cohort study," Cancer Causes \& Control, vol. 20, no. 10, pp. 1939-1945, 2009.

[25] L. J. Marnett, "Lipid peroxidation-DNA damage by malondialdehyde," Mutation Research/Fundamental and Molecular Mechanisms of Mutagenesis, vol. 424, no. 1-2, pp. 83-95, 1999.

[26] H. Wei, X. Zhang, J. F. Zhao, Z. Y. Wang, D. Bickers, and M. Lebwohl, "Scavenging of hydrogen peroxide and inhibition of ultraviolet light-induced oxidative dna damage by aqueous extracts from green and black teas," Free Radical Biology and Medicine, vol. 26, no. 11-12, pp. 1427-1435, 1999.

[27] I. N. Zelko, T. J. Mariani, and R. J. Folz, "Superoxide dismutase multigene family: a comparison of the CuZn-SOD (SOD1), Mn-SOD (SOD2), and EC-SOD (SOD3) gene structures, evolution, and expression," Free Radical Biology and Medicine, vol. 33, no. 3, pp. 337-349, 2002.

[28] B. Chris, V. M. Marc, and I. Dirk, "Superoxide dismutase and stress tolerance," Annual Review of Plant Physiology and Plant Molecular Biology, vol. 43, no. 1, pp. 83-116, 1992.

[29] H. Willekens, C. Langebartels, C. Tire, M. Van Montagu, D. Inze, and W. Van Camp, "Differential expression of catalase genes in Nicotiana plumbaginifolia (L.)," Proceedings of the National Academy of Sciences, vol. 91, no. 22, pp. 10450-10454, 1994.

[30] B. C. Wilke, M. Vidailhet, A. Favier et al., "Selenium, glutathione peroxidase (gsh-px) and lipid peroxidation products before and after selenium supplementation," Clinica Chimica Acta, vol. 207, no. 1-2, pp. 137-142, 1992.

[31] G. Yeoh, S. Barton, and K. Kaestner, "Preface," The International Journal of Biochemistry \& Cell Biology, vol. 43, no. 2, p. 172, 2011. 
[32] A. G. Porter and R. U. Jänicke, "Emerging roles of caspase-3 in apoptosis," Cell Death \& Differentiation, vol. 6, no. 2, pp. 99-104, 1999.

[33] I. Budihardjo, H. Oliver, M. Lutter, X. Luo, and X. Wang, "Biochemical pathways of caspase activation during apoptosis," Annual Review of Cell and Developmental Biology, vol. 15, no. 1, pp. 269-290, 1999.

[34] S. W. Lowe, H. E. Ruley, T. Jacks, and D. E. Housman, "p53dependent apoptosis modulates the cytotoxicity of anticancer agents," Cell, vol. 74, no. 6, pp. 957-967, 1993.

[35] C. Corbiere, B. Liagre, F. Terro, and J.-L. Beneytout, "Induction of antiproliferative effect by diosgenin through activation of $\mathrm{p} 53$, release of apoptosis-inducing factor (AIF) and modulation of caspase- 3 activity in different human cancer cells," Cell Research, vol. 14, no. 3, pp. 188-196, 2004.

[36] A. Saramaki, C. M. Banwell, M. J. Campbell, and C. Carlberg, "Regulation of the human p21(waf1/cip1) gene promoter via multiple binding sites for p53 and the vitamin D3 receptor," Nucleic Acids Research, vol. 34, no. 2, pp. 543-554, 2006.

[37] T. Agorastos, A. F. Lambropoulos, T. C. Constantinidis, A. Kotsis, and J. N. Bontis, "P53 codon 72 polymorphism and risk of intra-epithelial and invasive cervical neoplasia in Greek women," European Journal of Cancer Prevention, vol. 9, no. 2, pp. 113-118, 2000.

[38] S. Y. Chung, M. Pius, and X. Meng, "Inhibition of carcinogenesis by tea," Annual Review of Pharmacology and Toxicolog, vol. 42, no. 1, pp. 25-54, 2002.

[39] H. N. Graham, "Green tea composition, consumption, and polyphenol chemistry," Preventive Medicine, vol. 21, no. 3, pp. 334-350, 1992.

[40] A. B. Federici, "Clinical and molecular markers of inherited von Willebrand disease type 3: are deletions of theVWFgene associated with alloantibodies to VWF?," Journal of Thrombosis and Haemostasis, vol. 6, no. 10, pp. 1726-1728, 2008.

[41] P. Wu, S. Liu, J. Su et al., "Apoptosis triggered by isoquercitrin in bladder cancer cells by activating the AMPK-activated protein kinase pathway," Food Function, vol. 8, no. 1, pp. 3707-3722, 2017.

[42] T. Nabekura, "Overcoming multidrug resistance in human cancer cells by natural compounds," Toxins, vol. 2, no. 6, pp. 1207-1224, 2010.

[43] A. Ganeshpurkar and A. K. Saluja, "The pharmacological potential of rutin," Saudi Pharmaceutical Journal, vol. 25, no. 2, pp. 149-164, 2017.

[44] M. Kotani, M. Matsumoto, A. Fujita et al., "Persimmon leaf extract and astragalin inhibit development of dermatitis and IgE elevation in NC/Nga mice," Journal of Allergy and Clinical Immunology, vol. 106, no. 1, pp. 159-166, 2000.

[45] S. K. Amoah, L. P. Sandjo, J. M. Kratz, and M. W. Biavatti, "Rosmarinic acid-pharmaceutical and clinical aspects," Planta Medica, vol. 82, no. 5, pp. 388-406, 2016.

[46] G. P. Bolwell, M. Mavandad, D. J. Millar, K. J. Edwards, W. Schuch, and R. A. Dixon, "Inhibition of mRNA levels and activities by trans-cinnamic acid in elicitor-induced bean cells," Phytochemistry, vol. 27, no. 7, pp. 2109-2117, 1988.

[47] M.-P. Gonthier, M.-A. Verny, C. Besson, C. Rémésy, and A. Scalbert, "Chlorogenic acid bioavailability largely depends on its metabolism by the gut microflora in rats," The Journal of Nutrition, vol. 133, no. 6, pp. 1853-1859, 2003.

[48] M. Kim, S.-Y. Choi, P. Lee, and J. Hur, "Neochlorogenic acid inhibits lipopolysaccharide-induced activation and pro-inflammatory responses in BV2 microglial cells," Neurochemical Research, vol. 40, no. 9, pp. 1792-1798, 2015.
[49] X. Liu, K. Huang, Z. Niu, D. Mei, and B. Zhang, "Protective effect of isochlorogenic acid B on liver fibrosis in non-alcoholic steatohepatitis of mice," Basic \& Clinical Pharmacology \& Toxicology, vol. 124, no. 2, pp. 144-153, 2019.

[50] J. K. Yu, C. H. Yue, Y. R. Pan et al., "Isochlorogenic acid C reverses epithelial-mesenchymal transition via down-regulation of EGFR pathway in MDA-MB-231 cells," Anticancer Research, vol. 38, no. 4, pp. 2127-2135, 2018. 


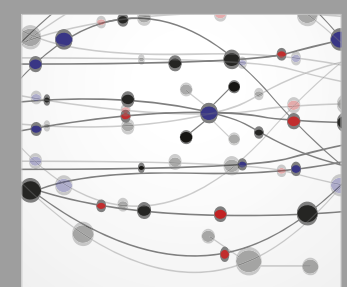

The Scientific World Journal
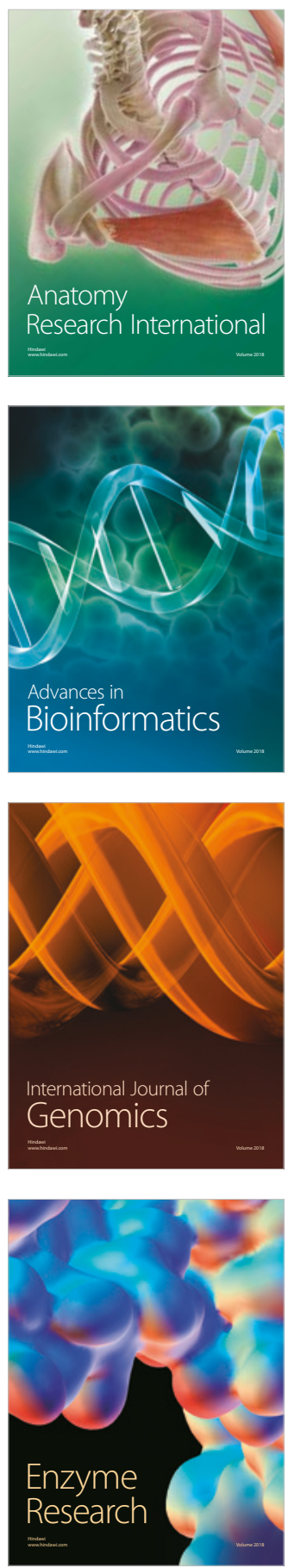
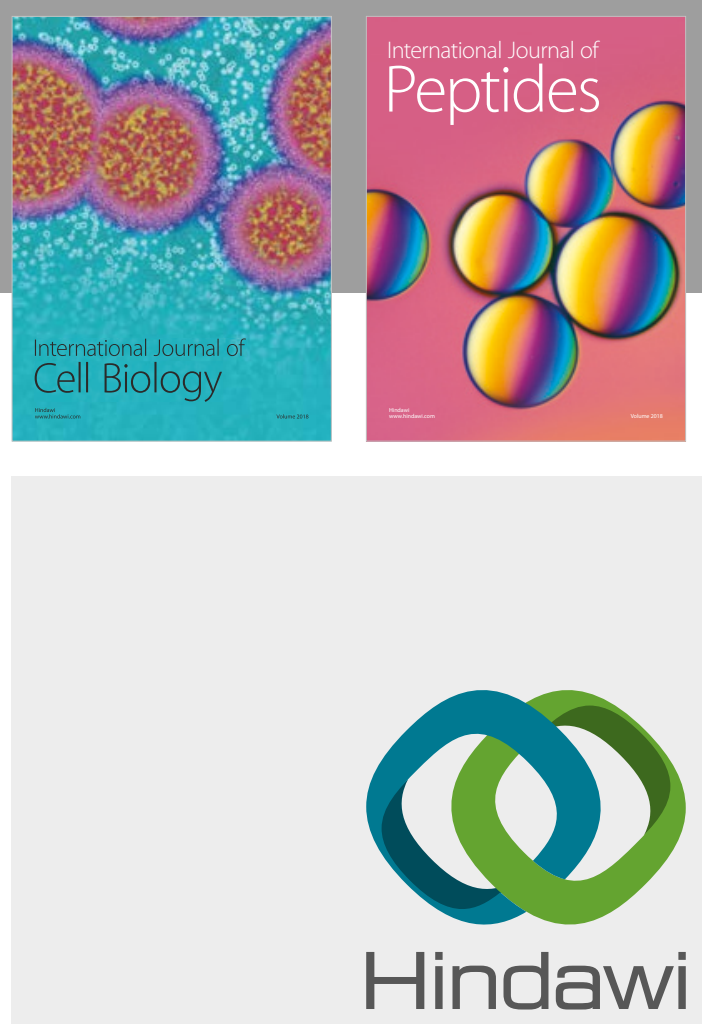

Submit your manuscripts at

www.hindawi.com
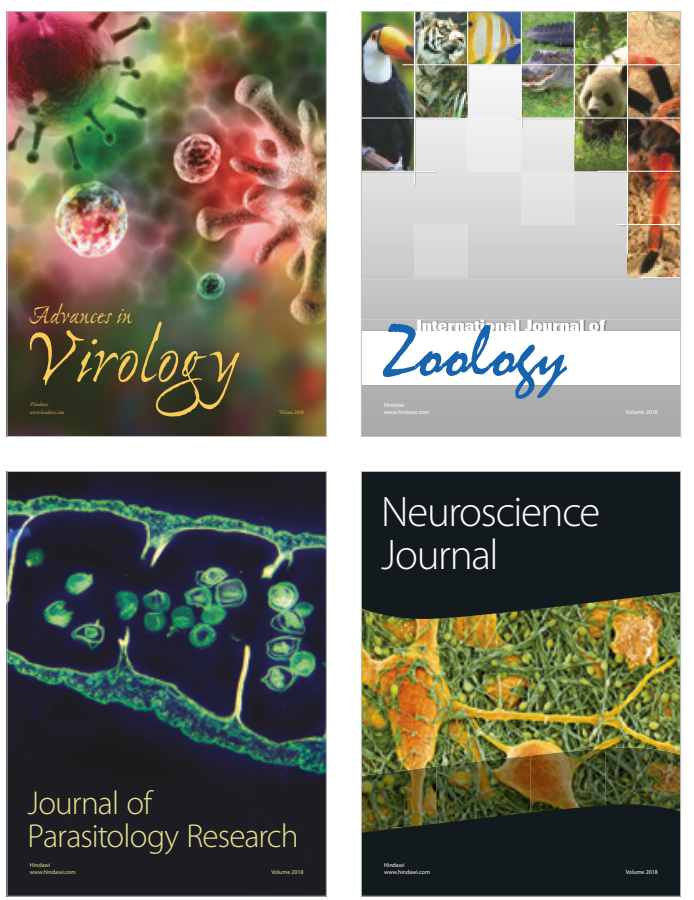
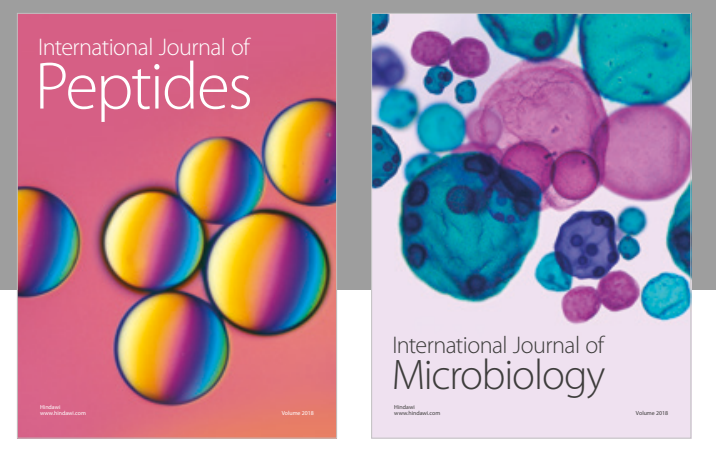

nternational Journal of Microbiology
Journal of
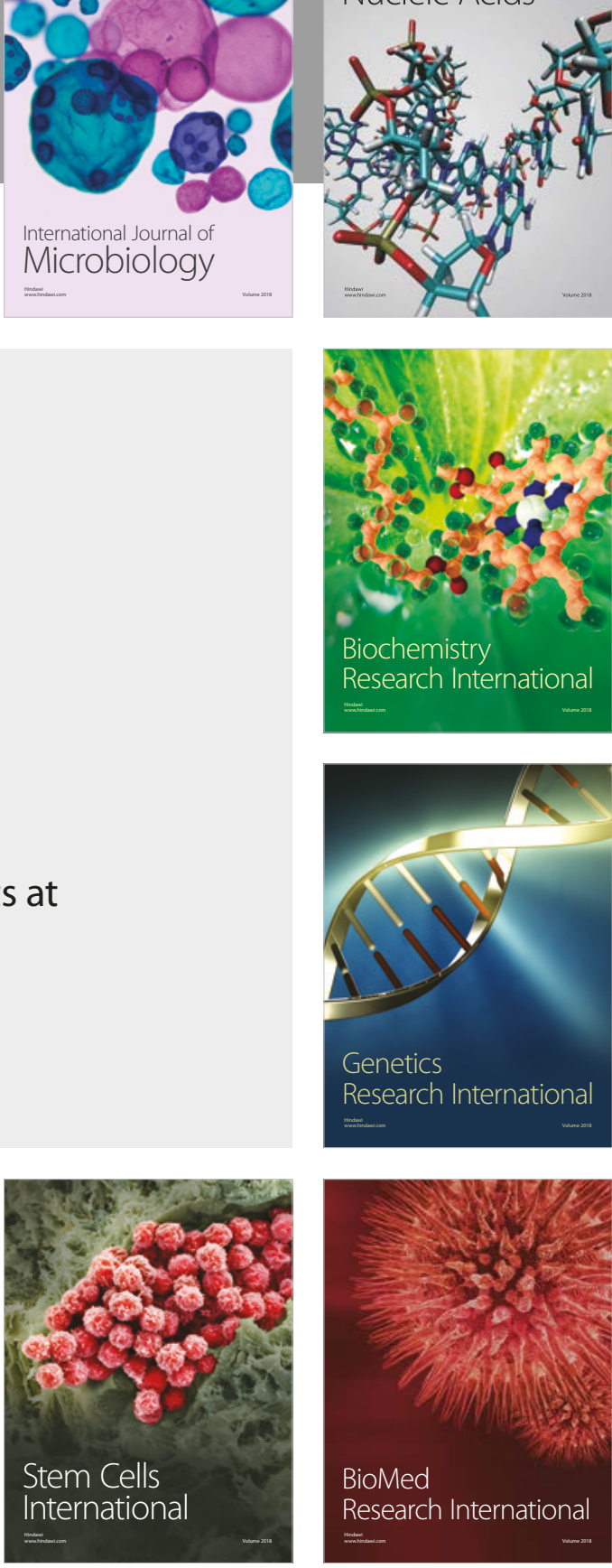
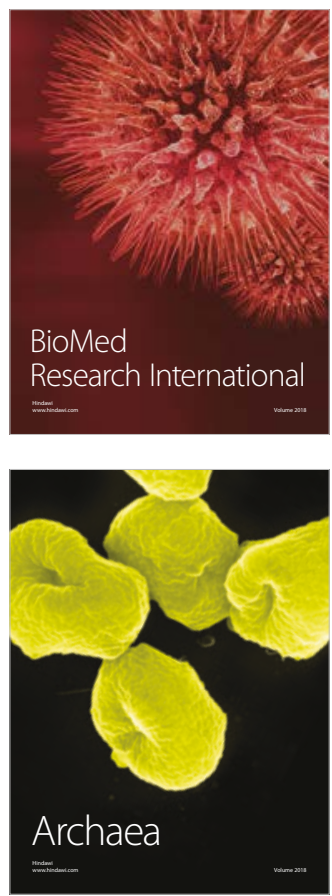